\title{
Humanistyka performatywna
}

ABSTRACT. Krajewska Anna, Humanistyka performatywna [The performative humanities]. „Przestrzenie Teorii" 29. Poznań 2018, Adam Mickiewicz University Press, pp. 31-85. ISSN 1644-6763. DOI 10.14746/pt.2018.29.2.

This article foregrounds the collapse of the binary opposition between drama and theatre that in literary and theatre discourses are traditionally recognized as wholly separate art forms, with the former based on words and the latter based on live performances. The present author argues that by applying a performative perspective on art in its varied forms and introducing the category of the entanglement of matter and meaning, derived from quantum physics, a non-antagonistic approach to drama and theatre is still possible. The argument that sees literature as a performative art, adopted by the author, provides additional support.

This article shows how changes in the very notion of the text as well as in the ontological status of literature itself have had their effect on the transformations of beliefs and conceptions grounded in the vision of the humanities understood as "the textual world" to produce the concept of "entangled world" instead. This being the case, the author proposes to depart from the concept of "text" (no matter how restructured or redefined), abandon thinking in categories of network structures (even Latour's actor-network's theory), and discard dialectical or holistic approaches (even the theory of cognitive blending - "cognitive amalgams") in favour of emergent "entanglement acts", anamorphic perspective in art reception and synaesthetic discourses. By studying experiences related to performativity in the arts and discourses related to performance studies, the article goes to show the changes currently going on in the humanities and transforming them into the perfomative humanities in the process.

KEYWORDS: drama, theatre, performance, performative humanities

Jestem w teatrze. Oglądam Wielkiego Fryderyka w reżyserii Jana Klaty w Teatrze Polskim w Poznaniu. Oglądam spektakl w repertuarowym teatrze według prawie zapomnianej historycznej sztuki, a ściślej - powieści dramatycznej, Adolfa Nowaczyńskiego. Oglądam spektakl. Nie, nie, co piszę! Nie oglądam adaptacji bardzo nieteatralnego (Lesedrama) dramatu, ale... czytam tekst pojawiający się na ekranach ustawionych po obu stronach sceny. Świecące liczne ekrany przyciagają wzrok, sprawiając, że odczuwam przymus lektury. Czytam zatem z prompterów rozmieszczonych w przestrzeni scenicznej tekst dramatu (który w końcu dobrze znam!), myśląc ze złościa - czy ja muszę czytać tekst w teatrze, czy ja jestem aktorka, by w dodatku czytać z promptera (jakbym nie zdążyła nauczyć się tekstu na pamięćc), czy ja jeszcze do tego muszę czytać „,skokowo”, co chwilę przenosząc wzrok z jednego na drugi ekran (nie przyszłam tu, by powielać sposób odbioru programów informacyjnych, czyli wielokrotnie przeskakiwać z okna

${ }^{1}$ Por. A. Kyzioł, Pamięć nieabsolutna, „Polityka” 2018, nr 28 [11.07-17.07.2018], s. 72-74. 
obrazu na pasek pisma i jeszcze rejestrować toczący się w studio dialog dziennikarza z zaproszonymi gośćmi)... Ale przecież zaraz zauważam, że zmieniam ekrany wraz z ruchem chodzących na scenie aktorów, czytam jakby równocześnie w trakcie śledzenia postaci. Nie tylko podążam za ich ruchem, ale słyszę ich głos jakby „na” moim czytaniu (kto w końcu czyta tekst: ja czy oni?). Słyszę swoje czytanie mówione przez aktorów, a widzę, jak ich gra, gesty, ruch, intonacja interpretuja wyświetlany tekst.

Nadal obserwuję więc swoje czytanie. W scenie z bajkami coś się zmienia. Nagle tekst recytowanych ze sceny utworów Ignacego Krasickiego przestaje być wyrazisty, zaciera go zgrzyt dźwięku/muzyki/hałasu - przestaję rozumieć słowa, po których zostaje jedynie, z trudem przebijający się przez magmę dźwiękową kakofonię niszczącą muzykę, ślad głosu aktora. Wymazywanym słowom towarzyszy pełen tekst, widzę na ekranach jego zapis - czytam (i choć znam bajki warmińskiego biskupa na pamięć, wydaje się, że nie słyszę już nawet swego głosu wewnętrznego), świdrujący dźwięk zakłóca odbiór i... każe czytać. Zamknięcie oczu nie pomaga, bo grozi utratą kontroli nad teatralną scena. Teraz z kolei ja czytam „na” zamazywanym, coraz bardziej nieczytelnym, głosie aktorów.

Kim jestem - czytelnikiem starego dramatu, widzem czytającym tekst pojawiający się jako zapis (tekst jako aktor?) na scenie, suflerem śledzącym tekst scenariusza, krytykiem teatralnym sprawdzającym umiejętności aktora... Nie, nie, co piszę! Jestem widzem w teatrze - czytam tekst dramatu.

Jestem w domu. Otwieram, właśnie przywiezione z Wrocławia, nowe wydanie sztuki Stanisława Ignacego Witkiewicza Gyubal Wahazar, czyli na przetęczach bezsensu. Nieeuklidesowy dramat w czterech aktach ${ }^{2}$. Czytam dramat wydany w formacie A 4, liczący przeszło 300 stron, ciężki volumen, wydanie papierowe, ilustrowane. Czytam dramat. Nie, nie, co piszę! Nie czytam dramatu, ale... reżyseruję spektakl, stwarzam mój własny teatr osobny, dramat układam po swojemu. Utwór Witkacego został bowiem opracowany w 2017 roku przez studentów PJATK (Polsko-Japońskiej Akademii Technik Komputerowych w Warszawie) jako projekt, nazwijmy go umownie: performatywnego czytania. Zaczynam zatem lekturę od zrealizowania instrukcji podanej na skrzydełku okładki, czyli wgrywam odpowiedni program i do czytania używam komórki. Myślę ze złością: a po co mi te techniczne „procedery”, dość dawno już uruchomiłam (podczas seminarium z doktorantami) metodę odbioru/tworzenia powieści opartą na użyciu QR-kodów w trakcie zaproponowanej przez uczestników spotkań interaktywnej lektury

${ }^{2}$ S.I. Witkiewicz, Gyubal Wahazar, czyli na przełęczach bezsensu. Nieeuklidesowy dramat $w$ czterech aktach/Vahazar or on the Uplands of Absurdity. Non-Euclidean Drama in Four Acts, przekł. C. Winiewska, adaptacja P. Fetherson, pod red. E. Sataleckiej we współpracy z M. Sady i M. Średniawa, projekt zespołu studentów PJATK, Warszawa 2017. 
Archetyptury czasu $u^{3}$, a dziś znów muszę instalować nowe aplikacje. Czy już nie lepiej sięgnać do wydań Witkacego pod redakcją Konstantego Puzyny czy Janusza Deglera? A może łatwiej by było po prostu zobaczyć tylko samą filmową animację, bez konieczności równoczesnego używania i egzemplarza książki, i komórki? To wahanie uzmysławia raz jeszcze, że uczestniczymy w odbiorczych splątaniach; niejednoznaczność, przeskakiwanie z typografii do ruchomego i wydającego dźwięki obrazu, z linii linearnego zapisu słów ${ }^{4}$ do linii rysunku nieopozycyjnego wobec pisma ${ }^{5}$ sprawia, że nasz odbiór przybiera cechy anamorfozy (chcesz oglądać „ruchome obrazy” - sięgasz po animację, chcesz czytać utwór - oddajesz się lekturze papierowego wydania dramatu Witkacego, chcesz zobaczyć obrazy słów - podziwiasz typograficzny projekt tekstu). Znamienne jest też i to, że równocześnie wchodzimy na scenę przekładu; dwujęzyczne polsko-angielskie wydanie sprawia, że przeskakujemy w lekturze także między tekstem polskim a angielskim, chcąc nie chcąc porównując przekład, ale raczej rozumiany jako „ciężar materii”, wygląd słów, ich interakcje z dźwiękiem i obrazem. Jest jeszcze i kolejne splątanie, które prowokuje podtytuł, rodzaj dedykacji poświęconej pamięci wybitnych twórców: „Witkacemu i Themersonom - studenci PJATK”. Dedykacja skierowana do Stefana i Franciszki Themersonów odsyła zaraz do działalności awangardowych artystów, których eksperymenty zainspirowały studentów i przywiodły do opracowania tego dramatograficznego ${ }^{6}$ projektu. Mamy zatem Witkacego przeczytanego przez sztukę Themersonów, a może i odwrotnie: to autor sztuki nieeuklidesowej ujawnił sposób myślenia podjęty później przez artystów sztuki hybrydowej. Można czytać Witkacego przez Themersonów, ale też Themersonów przez Witkacego.

Literatura staje się, wydarza, poza zapisem i równocześnie łącznie z litera, rozgrywa się w kontakcie z drukiem, obrazem i dźwiękiem, odrywa od tradycyjnie rozumianego tekstu wyrażonego tylko w słowach, obejmuje inne sztuki, przechodzi w teatr. Literatura zajmuje i równocześnie wytwarza przestrzenie performatywne ${ }^{7}$ rozumiane jako pola możliwości (wyjścia w obszary życia społecznego, kultury, w inne teksty, odmienne sztuki). Ożywione obrazy tańcza, wydają dźwięki (słychać szelest zgniatanych kartek, skrzyp otwieranych drzwi, trzask kości poruszających się w dziwnym „tańcu śmierci" namalowanych czaszek itp.), słowa w swych zapisach typograficz-

\footnotetext{
${ }^{3}$ Książka Andrzeja Głowackiego zapisana w postaci QR-kodów.

${ }^{4}$ O pojęciu linii por. J.H. Miller, Linia, przekład K. Hoffmann, „Przestrzenie Teorii” 2006, nr 6.

${ }^{5}$ Por. T. Ingold, Rysowanie, pisanie i kaligrafia, „Teksty Drugie” 2015, nr 4.

${ }^{6}$ O pojęciu dramatografii por. A. Krajewska, Dramatografia, „Przestrzenie Teorii” 2017, nr 27.

${ }^{7}$ Zob. A. Krajewska, Przestrzenie performatywne, „Przestrzenie Teorii” 2015, nr 24.
} 
nych formuja pole działania, postacie są tworzone przez nakładany kostium, zmieniają się w sposób, którym sama (ale jednak za pomocą programu) steruję. Co robię? Czy „uprzestrzenniam” dramat, „uczasawiam” rozwijający się w akcji obraz, „udźwiękawiam” typografię? Dokonuję animacji. A może, tworząc taką dramatografię, realizuję marzenie Witkacego o dramacie nieeuklidesowym w czterech aktach?

Tak, to jest rzeczywiście dramat nieeuklidesowy, dramat, który w tym wydaniu zrealizował ideę uprzestrzennienia i uplastycznienia oraz umuzycznienia i udźwiękowienia literatury (a nawet poniekąd stanął na drodze do zrealizowania marzenia Witkacego wprowadzenia literatury do „innej geometrii”). Witkacy przewidział interfejs? Witkacy wyprowadził literaturę $\mathrm{z}$ jednego wymiaru w przestrzeń kwantową? Bardziej prawdopodobne, by autor słynnego Autoportretu wielokrotnego w lustrach, 1915-1917 ustawiał na scenie promptery traktowane jak lustra, a nie szukał odpowiednich aplikacji na komórkę. A jednak projekt studentów PJATK mógłby się humorystycznie nazywać: „Gdyby Witkacy używał smartfona...”.

Kim jestem - czytelnikiem awangardowego dramatu, widzem teatru typograficznego, animatorem, kreatorem tekstu, technicznym w teatrze ustawiającym rekwizyty na scenie... Nie, nie, co piszę! Jestem czytelnikiem we własnym domu - reżyseruję sztukę Witkacego.

\section{Czytając w teatrze, reżyserując w czytaniu}

Oto więc mamy dwie paradoksalne sytuacje odbiorcze, których - pozorna jednak - paradoksalność polega na zburzeniu stereotypu binarnego ustawiania dramatu i teatru. Pierwsza sprowadza się do oznajmienia: „Jestem w teatrze - czytam dramat", a druga prowokuje do odwrócenia pierwszej: „Czytam dramat - jestem w teatrze”. Oto posługujemy się figurą chiazmu teatr i dramat, krzyżując swoje kompetencje, pokazują ich niesprzeczna naturę. Następuje „uteatralnienie” literatury i „uliteraturyzowanie” teatru.

Rodzą się pytania: czym jest zatem czytanie dramatu w teatrze? Jaki status ontologiczny ma tekst literacki, który czytamy, równocześnie oglądając spektakl lub wprowadzając w papierowe wydanie animacje? Czym jest teatr, który prowokuje lekturę zapisanego tekstu udramatyzowanej powieści? Czym jest „uteatralniony”, „,ugraficzniony”, „ufilmowiony”, dramat? Czy zatem da się przeprowadzić rozróżnienie między dramatem a teatrem?

Znamienne jest to, że w przypadku Wielkiego Fryderyka czytanie tekstu z ekranu nie oznacza po prostu wprowadzenia na scenę nowego medium

${ }^{8}$ Zob. E. Franczak, S. Okołowicz: Przeciw nicości: fotografie Stanistawa Ignacego Witkiewicza, Kraków, 1986, s. 63. 
(zabieg dziś całkowicie przyswojony, wręcz banalny, niemal powszechnie stosowany $\mathrm{w}$ teatrze i operze). Kultura czytania w teatrze jest znana tradycja, dawniej libretto otrzymywali widzowie wraz z programem - teraz często tekst wyświetlany jest na ekranach, zwłaszcza gdy trzeba tłumaczyć go z obcego języka. Nie tylko nie szokuja, ale spowszedniały ekrany na scenie $^{9}$. Pamiętam jeszcze dawne polskie dyskusje na temat umieszczenia na scenie... telewizora ${ }^{10}$ lub zademonstrowania pioruna na... stopklatce $^{11}$. Ekrany na scenie (niech już będą te „dyżurne”, często wykorzystywane przykłady) w Hamlecie Wooster Groop czy w spektaklach Romeo Castellucciego działały niebinarnie: wymazywały zarówno obraz, jak słowa, i równocześnie wzmacniały obraz i słowa. Akt wymazywania produkował tym intensywniej odbierany ślad.

Czytanie w Wielkim Fryderyku nie oznacza też, wbrew pozorom, wpisywania się w odżywającą w teatrze tendencję powrotu pełnych (przedstawianych prawie bez skreśleń) tekstów dramatów na scenie. To nie jest ironicznie nieco stosowany zabieg jako odpowiedź na zapotrzebowanie publiczności dające się streścić tak: chcieliście teksty, a nie fragmenty - macie słowa, tęskniliście za całościa - macie czterogodzinne spektakle.

Moim zdaniem w obu przypadkach - zarówno w Wielkim Fryderyku w reżyserii Jana Klaty, jak i w wydaniu Gyubala Wahazara Witkacego mamy do czynienia z głębszym procesem, podczas którego następuje, bardzo skutecznie pokazane, unicestwienie opozycji dramat-teatr, a dalej kolejnych kontradykcji, jak podziały sztuk na sztuki słowa, wizualne, wykonawcze. To bardzo szerokie zagadnienie, do którego powrócę w dalszych częściach tekstu, a rozwinięcie zostawię na inną okazję.

W Wielkim Fryderyku sam nośnik słów jest przecież obojętny (nieważne, czy czytamy tekst z papierowej, drukowanej książki, czy z ekranu Kindla, czy z promptera). W spektaklu Klaty ekran jedynie ujawnia jako zdarzenie sam akt czytania (pokazując jego wymiar performatywny), splątuje słowa z gra aktorów, z zapisem i dźwiękiem, zamazując zarówno układ linearny: dramat - teatr, jak i podkreślając anamorficzność odbioru. Niczego na nic nie przekładamy - ani w sensie przekładu intersemiotycznego, ani nawet w znaczeniu przekładu z języka obcego (jeśli pojawiają się fragmenty obcojęzyczne, to na ekranach sa podawane w oryginale, bez tłumaczenia). Różne języki, niekiedy zniekształcane brzmieniowo słowa, grają swą obcościa, a podlegając prześmiewczym kontaminacjom, stapiają się z ironicznymi

\footnotetext{
${ }^{9}$ Por. M. Błaszczak, Ekrany i lustra w polskim dramacie wspótczesnym, Poznań 2009.

${ }^{10}$ Por. J. Ciechowicz, Ich troje. Telewizja jako osoba dramatu, [w:] Teatr-media - kultura, pod red. D. Fox i E. Wąchockiej, Katowice 2006.

${ }^{11}$ Por. Balladyna J. Słowackiego w reż. A. Hanuszkiewicza w Teatrze Narodowym w Warszawie, premiera w 1974 roku.
} 
gestami i wymuszanymi na partnerach dialogu reakcjami (niekiedy trudno oprzeć się wrażeniu, że gdzieś w tle słychać Gombrowiczowski groteskowy chichot, na przykład w scenie recytacji wiersza przez Justynę, która, schylając się coraz niżej do opuszczanego przez Fryderyka powoli w dół mikrofonu, w istocie przeżywając gorycz poniżenia, oddaje wymuszony ukłon władcy, odwrotnie jak to czyni Iwona ze sztuki Witolda Gombrowicza Iwona księżniczka Burgunda, która z kolei wymusza swą „nijaką” postawą ukłon dworu). Poniżenie jako element autorytarnej władzy jest dobrze rozpoznana taktyką postępowania z potencjalnymi oponentami. Wielki Fryderyk Klaty pokazuje przecież między innymi procesy korozji, zmiękczania oporu, wdrażania postaw konformizmu i uległości wobec tyranizującej społeczeństwo władzy. Dlatego też tak ważne w tym spektaklu okazało się splecenie poniżających słów z upokarzającym działaniem, władczych gestów z obłudną mowa, bezkarności siły wobec racji bezsilnych. I może właśnie dlatego u Klaty tak ważny jest tekst Nowaczyńskiego, że przyciaga inne teksty, budzi rozmaite, indywidualne skojarzenia (jak choćby moje, związane z tekstem Włodzimierza Wysockiego, a ściślej z fragmentem słynnej piosenki o nienawiści - zarówno do gwałtu, przemocy, jak i do bezsilności, którego, rzecz jasna, nie słyszymy ze sceny, ale ewokujemy z pamięci).

Samo pojawienie się tekstu do czytania na teatralnej scenie (i to łącznie z zachowaniem oryginalnej „wielojęzyczności” dramatu Nowaczyńskiego, w którym przecież funkcjonują archaizmy, językowe zbitki, zwroty obcojęzyczne, przekształcone frazy gatunków mowy itp. - nie tłumaczone jednak na ekranach, jak byśmy tego oczekiwali, przyzwyczajeni do istniejących, nie tylko w filmach, ale także wyświetlanych coraz częściej na operowych scenach, paskach tłumaczeń) pokazuje, moim zdaniem, parę podstawowych spraw związanych z performatywnym charakterem języka. Język jest obecny jako materia (konkretny: widoczny w zapisie i równocześnie zrealizowany w mowie). Jest narzędziem przemocy i władania (ironia, zacieranie znaczeń, odkształcanie brzmień itp.). Przestaje mieć znaczenie jednorodność językowa wypowiedzi (wielość języków, nawet za cenę ich niezrozumienia, okazuje się ważna tak, jak istotna była dla Witkacego, jak znaczące jest użycie historycznej postaci języka japońskiego w teatrze kabuki czy posługiwanie się archaicznym językiem kawi przez dalanga, prowadzącego rytualny spektakl, $\mathrm{w}$ jawajskim teatrze cieni). Jest też jednak jeszcze demonstrowaniem sposobów przekształcania rozumienia literatury jako sztuki słowa w „sztukę splątaną" (zacierająca kryteria podziału sztuk pod względem tworzywa, ale też znosząca myślenie o świecie wyłącznie jako o bycie niezależnym od językowego ustanawiania).

Te dwa przykłady pokazuja sytuacje performatywnego wytwarzania pola, na którym zachodzi splątanie teatru i dramatu. Najpierw delikatnie 
odwracając kierunki tradycyjnie przyjętych działań (od dramatu do teatru oraz od teatru do dramatu). Sytuacja bycia w teatrze rodzi akt lektury tekstu sztuki, a lektura dramatu w domowym zaciszu powoduje akt kreacji teatralnej sceny. Potem, zwracając uwagę na wykorzystywanie pośrednich narzędzi technicznych do odbioru zarówno teatru (promptery), jak i dramatu (aplikacja na komórkę), traktowanych już nie tylko jako „rekwizyty” na scenie, ani jako media uczestniczące w projekcji sztuki, ale widzianych jako materia samej sztuki, nie tyle wyraz inter- czy postmedialności, ile trwałego elementu decydującego o istocie każdej sztuki rozpoznawalnej ze względu na schematy i scenariusze jej odbioru i kodowania ${ }^{12}$. Kolejno unicestwiając jej granice, akcentujac performatywność, czynimy ze sztuki próbę budowania rzeczywistości równocześnie naszej i alternatywnej, pozwalającej pozostając $\mathrm{w}$ granicach swego świata - zanurzyć się w świat zewnętrzny wobec potocznego doświadczenia, po to, by to swoje doświadczenie niejako od zewnątrz, jak z widowni, „zobaczyć” i powtórnie oba doznania splątać. Terminu splatanie ${ }^{13}$ (w nawiązaniu do zastosowań w fizyce kwantowej) używałam wielokrotnie (jako splątanie literackie, splątanie sztuk, splątanie jako kategoria odbioru anamorficznego). Splątanie odnosi się zarówno do problemu syntezy sztuk (dzieła hybrydowe), jak i kwestii iterowalności (wielość wersji w różnych środkach przekazu), ale nie będzie zachodzić bez aktu jego uruchomienia przez poznajacy podmiot, który nie tyle pragnie uchwycić istotę sztuki, ile, aranżując różne dramaturgie, równocześnie stara się dokonać analizy aktów własnego poznania. W badaniach nad twórczością artystyczną idziemy zatem znacznie dalej, niż tylko pokazując obszary „pomiędzy” sztukami, w istocie próbujemy znosić wszelkie opozycje dotyczące sposobów naszego poznania. Szukamy nowych jakości procesu samego doświadczania, jakości tkwiących w ustanawianiu aktów splątania, w których przestaje istnieć opozycja wnętrza i zewnętrza - wyjście ze środka ku zewnętrzu sprawia, że to, co zewnętrzne przyjmuje już nacechowanie środka. Splątanie uruchamia zatem performatywny wymiar aktu poznania. $\mathrm{Na}$ gruncie fizyki pokazał ten efekt znakomicie Erwin Schrödinger, tworząc eksperyment myślowy znany pod hasłem „kot Schrödingera” ${ }^{14}$, określający hipotetyczny stan, w którym kot jest równocześnie żywy i martwy. $\mathrm{Na}$ gruncie teatru rozumiał zjawisko i przedstawił artystycznie Samuel

${ }^{12}$ Por. W. Faulstich, Estetyka filmu. Badania nad filmem science fiction „Wojna światów” (1953/1954) Byrona Haskina, przekł. M. Kasprzyk, K. Kozłowski, przedm. i oprac. K. Kozłowski, Poznań 2017.

${ }^{13}$ Po raz pierwszy wprowadziłam termin splatanie w: A. Krajewska, Splatanie literackie, „Przestrzenie Teorii” 2012, nr 17.

${ }^{14}$ Por. Paradoks kota Schrödingera, [w:] J. Baggott, Teoria kwantowa, Warszawa 2013, s. 196. 
Beckett, dając wyraz takiej antybinarnej postawie na przykład w sztuce telewizyjnej(?), filmowej(?), teatralnej(?), tanecznej(?), pantomimicznej(?), dramatycznej(?), jaka jest (we wszystkich swoich prezentowanych wersjach) Kwadrat. Modelowym wręcz przykładem likwidacji opozycji pojęcia wnętrze/zewnętrze jest aktorstwo shite - głównego aktora posługującego się maską w teatrze nō. W jego grze następują procesy wielokrotnego splątania, na przykład twarzy z maska, bycia równocześnie różnymi osobami, oglądania siebie z perspektywy widza itp. Wobec doświadczeń japońskiego teatru nō - próby pisania o dramaturgii przekroczeń w wydaniu teoretyków świata Zachodu wydają się nikłe ${ }^{15}$. Najbardziej fascynujący jest fakt możliwości porównania procesów zachodzących w kwantowym świecie i na scenie metafizycznego teatru nō.

Na użytek tego szkicu chciałabym więc wyeksponować kres jednej z ważnych cech myślenia związanego z kulturą Zachodu, to jest binarności. Zwolennicy ujmowania świata w opozycjach binarnych mówią zwykle o celowości takiego postępowania ze względu na jego przejrzystość. Wyodrębnianie i układanie przeciwieństw jest znakomite dydaktycznie, bo utwierdza w poczuciu pewności poznawczej, chroni przed nieładem i chaosem, sprawia, że wszystko staje się jasne i oczywiste. W takich procedurach dominuje porządek i moc rozstrzygania. Jednakże binarność, tak oczywista dla myślenia Zachodu, zupełnie nie sprawdza się w innych kulturach, zwłaszcza Dalekiego Wschodu. Pytanie skierowane do mieszkańców Bali na przykład o granice domostwa i cmentarza okazuje się dla nich zaskakujące, ponieważ takiej granicy nie ma - popioły zmarłych, spoczywające w specjalnych architektonicznie wkomponowanych w przestrzeń domu miejscach, towarzysza żywym jako duchy przodków; jesteśmy spleceni razem, żywi wraz z naszymi bliskimi, którzy odeszli - stanowimy jedność. W japońskim teatrze nō maska nie zakrywa twarzy, ale jest z nią sprzężona, pozwala zrozumieć siebie poprzez widzenie zewnętrzne, oczami widza, a z drugiej strony umożliwia przeistaczanie się postaci w istoty innego rzędu czy wymiaru, na przykład duchy. Jeśli w kulturach Wschodu istnieje odgraniczenie, bariera, to jest ona nieustannie przekraczana, ustanawiana na moment po to, by subwersalnie dokonać się mogło jej zniesienie, przemieszczenie, i zarazem inne

${ }^{15}$ Na uwagę zasługuje na przykład książka Paula Fostera Beckett and Zen. A Study of Dilemma in the Novels of Samuel Beckett, London 1989 (dotycząca jednak prozy, nie twórczości dramatycznej Becketta), krótkie fragmenty książki Richarda Shustermana, Myślenie ciała. Eseje z zakresu somaestetyki, Kraków 2016, (poświęcone aktorstwu shite), Estery Żeromskiej Maska na japońskiej scenie. Od pradziejów do powstania teatru nō. Historia japońskiej maski $i$ zwiazanej z niq tradycji widowiskowej, Warszawa 2003. A także w szerszym kontekście udziału pojęć z zakresu sztuki w dyskursie filozoficznym, na temat masek transformacyjnych Catherine Malabou, Plastyczność u zmierzchu pisma. Dialektyka, destrukcja, dekonstrukcja, przekł. P. Skalski, Warszawa 2018. 
ustanowienie budowane na tym samym. Przerwanie zachodzącego procesu jest równocześnie jednoznaczne z jego powtórzeniem, odbudową poprzez zauważenie i powtórne włączanie elementów brakujących. Usłyszeć klaskanie jednej dłoni lub szum drzewa, gdy nie wieje wiatr - oto zadania stawiane przez buddyjskich mnichów swoim adeptom. Przestawienie się człowieka Zachodu na inny tryb myślenia o otaczającej go rzeczywistości sprawia, że zaczynamy rozumieć, czym są złudzenia naszego umysłu wsparte na silnych filarach oświeceniowego rozumu i przedeinsteinowskiej fizyki.

\section{Teatr kontra dramat}

Relacja dramatu i teatru okazuje się wręcz modelową sytuacją wyjściową do opisu znacznie szerszych i głębszych procesów, które zaszły na obszarze sztuki, a dalej także współczesnej humanistyki. Rozwinięcie tak szerokiego tematu, jak już wcześniej zaznaczałam, pozostawiam na inną okazję. Aby jednak zarysować, choć w wielkim skrócie, taką nową perspektywę patrzenia na dramat i teatr w ich wzajemnym sprzężeniu, przypomnijmy pokrótce dobrze znane, wielokrotnie opisywane, tendencje w traktowaniu obu sztuk. Dopiero bowiem na tym tle widać wyraźnie, że możliwość zmiany sposobu postrzegania ich relacji umożliwia przyjęcie innej, niedualnej, wizji świata. Dwudziestowieczne koncepcje wzajemnych związków dramatu i teatru układają się na sposób binarny: od ostrego antagonizmu po łagodna relacyjność. To przypomnienie jest ważne, by dostrzec linię rozwoju burzliwych, „niebezpiecznych związków” sztuki przedstawiania (w rozumieniu mimesis jako odwzorowania, reprezentacji oraz uobecniania na scenie w spektaklu). Rozdzielenie dramatu (jako sztuki literackiej, słownej) od teatru (jako sztuki wykonawczej, wielotworzywowej) rozpoczęło się znacznie wcześniej, tj. w erze druku, który oderwał słowa od sceny, usztywnił je zapisem i spowodował, że mogły być powielane bez końca w tysiącach egzemplarzy. Dramat uzyskał zatem postać taka jak powieść czy wiersz, mógł być czytany i odbierany osobno, poza teatrem, w procesie jednostkowej lektury. Dramat (może na powrót?) stał się rodzajem poezji dramatycznej ${ }^{16}$, która jednak tęskniła stale do teatru, do głosu aktora, do przestrzeni, w której gest, spojrzenie, kostium uobecni się, unaoczni, wybrzmi w pełni dźwięku, kształtu i koloru. Czy jednak rzeczywiście tylko dramat dopominał się sceny? A czyż wiersz nie dopominał się wygłoszenia, a powieść zobaczenia na scenie (choćby tej wizualizowanej w wyobraźni)? Czy istniejące w dramacie didaskalia naprawdę mogły zdecydować o jego pragnieniu sceny?

${ }^{16}$ Por. H. Życzyński, Teoria dramatu, Cieszyn 1922. 
Dramat i teatr stanęły wobec siebie w pozycji antagonistycznej chyba najsilniej w momencie stworzenia przez Stefanię Skwarczyńską w 1949 roku teatralnej teorii dramatu ${ }^{17}$, czyli propozycji zmian w trójpodziale Arystotelesa - liryka, epika, dramat - i zastapienia dramatu (jako formy niegotowej i niepełnej) teatrem (sztuką pełnowymiarowa, właściwa). Nikt nie lubi być wyrzucany, zwłaszcza tak zdecydowanie, z tak zaszczytnego miejsca.

Dramat stał się w takim układzie sztuką niechcianą. Oddany w ręce czytelników, wtłoczony w ramy literatury pojętej jako zapisane słowa, utrwalony w druku i powielany w niezliczonych kopiach uzyskał status dzieła literackiego, którym jednak niechętnie zajmowali się literaturoznawcy, pamiętając o teatralnym życiu dramatu. Niechętnie przyjmowany przez teatrologów (od początku powstania dyscypliny) stanowił ciało obce, uznany za dzieło niepełne, a nawet nie zawsze potrzebne, brane pod uwagę jedynie po to, by pokazać możliwości teatru, czyli proces adaptacji tekstu literackiego, dramatu, na scenę, rzutowanie literatury w przestrzeń teatru. Utrwalało się coraz mocniej poczucie, że tekst literacki podlega procesowi adaptacji scenicznej lub działaniom przekładu ( $w$ domyśle - przekładu intersemiotycznego). Zaczęto więc stawiać pytania o wierność inscenizacji wobec tekstu, a dalej widzieć i ujmować relacje między słownym przekazem utworu a sceniczną realizacją w kategoriach interpretacji.

Dramat znalazł (zawsze ich miał!) obrońców, literacka teoria dramatu wzięła jednak odwet. Relacja dramat a teatr uzyskała pierwsze rozszerzenie, zaczęła być rozpatrywana jako opozycja literatura a teatr. Jerzy Ziomek ${ }^{18}$ w Arystotelesowskim ujęciu sześciu składników tragedii (mythos, ethos, dianoia, lexis, opsis i melos) wyodrębniał specjalna pozycję opsis i melos jako czynników dotyczących innego poziomu kreacji dzieła scenicznego, czyli wystawienia, inaczej jeszcze oprawy scenicznej: wizualnej (plastyki, ruchu, tańca) oraz materii dźwiękowej (muzyki, pieśni, dźwięku). Czynił to po to, by wskazać na sytuację wykonawczą tekstu, układu dotyczącego słów, bohaterów, fabuły, idei. Projekt wykonania zawarty w tekście pozwalał na zaznaczenie odmienności tych dwóch składników w budowie tragedii. Miało to znaczenie pozytywne - pokazywało, jak wykonanie tekstu zmieniało jego postać, wprowadzało twórczą rolę wykonawcy tekstu (aktora, artysty teatru...). Sytuowało dramat nie tylko wobec teatru, ale szerzej wobec literatury (która, też jako liryka czy epika, zawierała projekty wykonania,

${ }^{17}$ S. Skwarczyńska, Zagadnienie dramatu, [w:] Problemy teorii dramatu i teatru, wybór i oprac. J. Degler, Wrocław 1988, s. 105-123 [pierwodruk „Przegląd Filozoficzny” 1949, z. 1-2, s. 102-126].

${ }^{18}$ J. Ziomek, Projekt wykonawcy $w$ dziele literackim a problemy genologiczne. Tekst wielokrotnie potem przedrukowywany, po raz pierwszy ukazał się w: Problemy odbioru i odbiorcy, pod red. T. Bujnickiego i J. Sławińskiego, Wrocław 1977. 
nawet wykraczające poza język i media danej epoki, jak radiowość dialogów Platona przy ich nieteatralności, filmowość powieści Fieldinga sprzed wynalazku kina itp.). Koncepcja Ziomka otworzyła pojęcie tekstu na zmiany ${ }^{19}$, akcentując udział odbiorcy jako wykonawcy dzieła. Nie bez wpływu takich prac, jak na przykład Roberta Jaussa, poświęconych horyzontowi oczekiwań odbiorczych ${ }^{20}$. Jednakże, zapewne wbrew intencjom Ziomka i twórców estetyki recepcji, utrwaliła zależność binarną dramatu i teatru, tyle że to jednak w większości dramat projektował teatr. Projekt wykonawcy w dziele literackim, sformułowany przez Jerzego Ziomka, rozwijany potem przez Dobrochnę Ratajczakowa pod hasłem: „dramat - sługa dwóch panów”, był próba przywrócenia teatrologom dramatu, wsparta wizją łagodniejszego, nieantagonistycznego pokazywania zależności między badaniami literatury i teatru. Propozycje takich relacyjnych ujęć, chociaż zwróciły uwagę na aktywność odbiorcy, niewiele zmieniły w zasadniczym rozumowaniu (pozostającym w polu myślenia dualnego) o istnieniu podziału sztuk na sztuki słowa i sztuki wykonawcze. Dramat mógł być nadal czytany w dwóch porządkach: literackim lub teatralnym. Literatura jednak niezmiennie pozostawała zapisem słów traktowanych jako wewnątrztekstowa dyspozycja, projekt wykonania scenicznego.

\section{Teksty dla teatru - teatry dla tekstu}

Pozostawaliśmy, jak się wydaje, na długo uwięzieni w wyobrażeniu literatury jako sztuki słowa przeciwstawionej sztukom wizualnym i wykonawczym. Mimo że nazwę sztuki wizualne zastapiła propozycja Williama Johna Thomasa Mitchella ${ }^{21}$, otwierająca tę klasyfikację na inne obszary, czyli - kulturę wizualną. Mimo że sztuki wykonawcze, związane przede wszystkim z teatrem, kiedy objęły performans i położyły akcent na działania odbiorcy, przekształciły się w sztuki performatywne. Mimo że obrazy wprowadzające zmienne ramy, tak zwane podwójne ramowanie ${ }^{22}$, prowokowały

${ }^{19}$ Szerzej omawiam propozycję Jerzego Ziomka w: A. Krajewska, „Zwrot dramatyczny” a literaturoznawstwo performatywne, „Przestrzenie Teorii” 2012, nr 17.

${ }^{20}$ H.R. Jauss, Historia literatury jako prowokacja, przeł. M. Łukasiewicz, posłowie K. Bartoszyński, Warszawa 1999 (por. zwłaszcza koncepcję „horyzontu oczekiwań”, s. 162/163).

${ }^{21}$ W.J.Th. Mitchell, Czego chcq obrazy? Pragnienia przedstawień, życia i miłości obrazów, przeł. Ł. Zaremba, Warszawa 2015.

${ }^{22}$ E. Goffman, Analiza ramowa. Esej z organizacji doświadczenia, przeł. S. Burdziej, Kraków 2010, R. Eshelman, Performatyzm, albo koniec postmodernizmu („American Beauty”), przeł. W. Szwebs i K. Hoffmann, „Przestrzenie Teorii” 2012, nr 17, J. Crary, Zawieszenia percepcji. Uwaga, spektakl i kultura nowoczesna, przekł. Ł. Zaremba, I. Kurz, red. nauk. i posłowie I. Kurz, Warszawa 2009. 
doświadczenie wizualne jako poznanie dramatyczne, wpisując także obszar wizualności w pola różnych teatrów, wymagających odmiennych percepcji. Mimo że budowano - już także w teatrach repertuarowych - spektakle operujace dokumentami, jak Czerwiec 56 w Teatrze Nowym w Poznaniu w reżyserii Izabelli Cywińskiej, w którym to teatr stwarzał z akt sądowych procesów pełnowymiarowy tekst dramatu. Mimo że, w końcu, zmieniła się postać samej literatury i podejście do spraw reprezentacji, prowadzące do zobaczenia sztuki słowa jako sztuki performatywnej (zarówno w wymiarze możliwości przestrajania na język związany z innymi mediami, jak i ze względu na konsekwencje przyjęcia i modyfikowania koncepcji Austinowskich aktów mowy w wypowiedziach artystycznych, a przede wszystkim poprzez zmianę odniesienia języka do świata na nieopozycyjna).

Sytuacja dramatu (czy z czasem szerzej literatury) przeciwstawionego teatrowi nie uległa przekształceniom nawet wtedy, gdy nastapiła zmiana kierunku i zauważono, że to raczej teatr wytwarza dramat ${ }^{23}$ (ściślej: buduje dramaturgię z tak zwanych tekstów dla teatru). Dramat kolejny raz został wypchnięty ze sceny i umieszczony w magazynie z napisem: literatura (i to znów w podtekście, przy milczącym założeniu aksjomatycznie rozumianej literatury jako zapisanego w słowach tekstu).

Po ukazaniu się książki Hansa-Thiesa Lehmanna Teatr postdramatycz$n y^{24}$ wszystko wydawało się już proste - oto dokonał się ostateczny zwrot: teatr nie wystawia już gotowych sztuk, ale jest miejscem przetwarzania różnych tekstów, z których fragmentów, cytatów czy innych rozmaitych odwołań tworzy spektakl. Teksty są wybierane spośród: dramatycznych i niedramatycznych, literackich i nieliterackich, artystycznych i nieartystycznych, mówionych i pisanych, profesjonalnie konstruowanych i spontanicznie bezpośrednich, a potem przywoływanych na wiele sposobów: cytowanych i przepisywanych, znalezionych i odkrywanych lub tworzonych i dostarczanych specjalnie dla danej sceny - krótko mówiąc: dramat zastapiły „teksty dla teatru”. Czyli, inaczej mówiąc, dramat traktowany był już tylko jako jeden z wielu „tekstów dla teatru”. Książka Lehmanna była swego czasu teatrologicznym bestsellerem, a zarazem niemal księga święta. Oto teatr okrzyknięto tworem postdramatycznym. Nie wchodząc

${ }^{23} \mathrm{O}$ tym, że teatr może wytwarzać dramat, wiadomo już było przed ustaleniami Hansa-Thiesa Lehmanna. To długa praktyka teatralna - najpierw spektakl, potem zapis - prowadząca od tak zwanej dramaturgii niearystotelesowskiej po częstą metodę pracy na scenach awangardowych teatrów, takich jak Jerzego Grotowskiego, na przykład w Apocalipsis cum figuris, czy Próby Tadeusza Kantora, czy Tadeusza Różewicza, na przykład Kartoteka rozrzucona, czy u innych współczesnych artystów.

${ }^{24}$ H.-Th. Lehmann, Teatr postdramatyczny, przeł. D. Sajewska i M. Sugiera, Kraków 2004 . 
w polemikę z tezami Lehmanna, odnotować w tym miejscu chciałabym jedynie pewien proces trafnie opisany w krytyce teatralnej, jak określiła zjawisko wykorzystując tytuł jednego z przedstawień Joanna Krakowska, jako - transfer. Dokonał się zatem transfer z teatru inscenizacji sztuk do teatru wytwarzania tekstów.

Ten transfer nie był przypadkiem, lecz skutkiem przemian dokonujących się w teatrze od końca lat dziewięćdziesiątych. I polegał na definitywnym opuszczeniu bezpiecznej przestrzeni teatru inscenizującego sztuki na rzecz teatru wytwarzającego na własne ryzyko teksty dramatyczne.

Teatr wytwarzał je przy tym niezmiernie ekologicznie - z wykorzystaniem surowców wtórnych. Teksty dla teatru to bowiem nieraz adaptacje i kompilacje wielu literackich źródeł; to parafrazy, przeróbki, pastisze znanych tekstów kultury, śmiałe kompilacje cytatów albo docu-dramy oparte na archiwaliach i relacjach świadków. [...] Transfer oznaczał więc przesiedlenie twórców i widzów na terytorium, gdzie z całej zwyczajowej teatralnej infrastruktury literackiej, konwencjonalnej i komunikacyjnej pozostały jedynie powidoki, szczątki, skojarzenia i wspomnienia ${ }^{25}$.

W wypowiedzi Krakowskiej brzmi wyraźnie koncepcja Lehmanna. W interpretacji teorii autora Teatru postdramatycznego zwraca uwagę ciekawe podkreślenie aktu odwrócenia: teraz to teatr wytwarza teksty dramatyczne. Podkreślmy tę zmianę kierunku, zmianę wygodnego, bo dobrze znanego i długo wykorzystywanego, traktu od dramatu do teatru na wyboistą drogę od teatru do tekstów dramatycznych.

Co zatem w praktyce oznaczał transfer? Nowe sposoby pracy - nieczęste dotąd w teatrze repertuarowym - jak „pisanie na scenie”. Nowy zawód - dotąd sporadycznie tylko uprawiany - „dramaturg”, który tym się różni od dramatopisarza, że jego praca kończy się nie przed rozpoczęciem prób, ale trwa aż do premiery. Nowe tematy - historyczne, archiwalne, rozliczeniowe, biograficzne, które wymagały nowych źródeł, nowych metod, nowego podejścia do pisania. Nowe strategie autorskie - kolaże, remiksy i parafrazy, recyklingi i kłusownictwo. Nowe zaangażowanie - ujawnienie i otwarte praktykowanie na scenie własnego światopoglądu. Nowa relacja z publicznością - oparta na oczekiwaniu nie tyle akceptacji, ile krytycznego myślenia. Transfer oznaczał też odstąpienie od kreowania na scenie światów na rzecz kwestionowania tych istniejących, zarówno realnych, jak fantazmatycznych. Odtąd reżyserzy, zamiast sięgać po sztuki dramatyczne, zaczęli zamawiać lub współtworzyć scenariusze przedstawień; zaczęło się przesiedlanie twórców z teatru interpretacji do teatru rewindykacji, a widzów - z przestrzeni przyjemności w przestrzeń konfrontacji ${ }^{26}$.

${ }^{25}$ J. Krakowska, Przesiedleni. Wstep, [w:] Transfer! Teksty dla teatru. Antologia, red. J. Krakowska, Warszawa 2015, s. 7.

${ }^{26}$ Tamże, s. 10. 
Przytaczany tu obszernie opis pewnego stanu rozwoju polskiego teatru współczesnego dokonany przez Krakowska jest bardzo ważny, trafny, obrazowy, prawdziwy. W pewnych fragmentach artykułu będę do niego jeszcze powracać.

Rodzi się jednak szersze pytanie o konsekwencje przyjęcia teatrologicznej koncepcji „tekstów dla teatru” dla dalszego sposobu przeciwstawnego traktowania relacji dramat-teatr w dyskursach różnych dyscyplin. Posługiwanie się pojęciem Lehmanna „teksty dla teatru” określa też dość jednoznacznie sposób widzenia podrzędnej pozycji literatury w teatrze. Moim zdaniem, nawet tak wydawałoby się nowatorskie zmiany, które zaszły $\mathrm{w}$ teatrze, nie przekreśliły jednak w dyskursie krytycznym pozycjonowania dramatu i teatru jako sił antagonistycznych. Wręcz przeciwnie - sprawiły, że w takim ujęciu jeszcze mocniej niż kiedykolwiek podkreślona została opozycyjność świata literatury wobec świata teatru.

Zapytajmy teraz, co się stanie, gdy przeczytamy wydane w antologii Transfer teksty nie tylko jako „materiał dla teatru”, ale potraktujemy je z cała świadomością niepoprawności (?) takiego postępowania - jako dramaty.

Można by wtedy wręcz odnieść wrażenie, że mamy coraz lepszy teatr i coraz gorszy (a może tylko zmieniający formułę dramatyczności?) współczesny dramat, który staje się coraz bardziej wypowiedzią publicystyczną i, co gorsza, powoduje, że i język jego opisu zaczyna być coraz częściej także wiązany bardziej z tekstem publicystycznym niż wypowiedzią naukowa odsłaniająca procesy określające sposoby funkcjonowania pola sztuki i jego uwikłań w rzeczywistość społeczną. Zapewne przesadzam, ale chciałabym w tym miejscu pokazać, że samo odwrócenie kierunku „przepływu” „z biblioteki sztuk dramatycznych w domenę tekstów dla teatru" ${ }^{27}$ nie przekreśla wciąż obecnego myślenia opartego na opozycjach (tu wartościowanych dodatnio na korzyść sceny), czyli: ,stary dramat - nowy teatr”(?). Dodatnio wartościowana jest natomiast sama czynność „czynienia” dramaturgii, czyli układania, komponowania, budowania z tekstowych strzępów nowego dramatu(?), tekstu kultury(?), widowiska teatralnego(?). Praca dramaturga w teatrze polega na uruchomieniu, różnymi sposobami, mechanizmów prowadzących do pozyskania nowego układu z wykorzystywanego wtórnie materiału dramatotwórczego. Mówiąc prościej - nie wystarczy, jak kiedyś $\mathrm{w}$ dawnym teatrze repertuarowym, dokonanie adaptacji tekstu na język sceny; konieczne staje się zbudowanie w trójwymiarowej przestrzeni teatru obejmującej także obszar widowni - spektaklu uczestnictwa (rozmowy, prowokacji, prezentowania różnych jakościowo wypowiedzi, aranżowania wielu możliwych sytuacji komunikacyjnych i prowadzenia dyskusji na ich temat).

${ }^{27}$ Tamże, s. 8. 
A co się dzieje z literaturą? Literatura, która w tym Lehmannowskim dyskursie już nie tylko razi swym językowym charakterem, ale, co więcej, staje się jakimś synonimem wsteczności, tradycjonalizmu i zepchniętego tam anachronicznego (co to bowiem znaczy „klasycznego” czy „regularnego”) dramatu wobec nowatorskiego, wychodzącego w życie, pełnowymiarowego teatru. Czyżby, mówiąc ironicznie, zrealizował się paradoksalnie postulat Stefanii Skwarczyńskiej - wygoniliśmy wreszcie dramat z teatru, uczyniliśmy z niego w najlepszym przypadku jedynie strzęp, wtórny odpad, „tekst dla teatru"? A może raczej koncepcja Antonina Artauda zaczyna przybierać kształt w polskim teatrze repertuarowym? Więc dlaczego wracają na scenę wielkie dramaty, na przykład pełnotekstowe Dziady Mickiewicza w reżyserii Michała Zadary czy Wesele Jana Klaty? Czy one też są już tylko „tekstami dla teatru"?

A może należałoby jednak inaczej postawić pytania, nie brnąc już dalej w zaprezentowany przeze mnie nieco ironicznie, parę zdań powyżej, hipotetyczny wywód „naiwnego” odbiorcy? W polskim współczesnym teatrze repertuarowym ani przecież nie zwyciężyła koncepcja Skwarczyńskiej, ani tryumfu nie odniosła wizja Artauda. Wystawia się Dziady i docu-dramy, powstają spektakle sięgające do wielkiego repertuaru dramatycznego, ale też i te zbudowane z tekstów niebędących, w znaczeniu tradycyjnej genologii, dramatami.

W historii teatru istniał jeszcze jeden - wart odnotowania w kontekście wątku sprzężenia dramatu z teatrem - nurt, który nazywano metateatrem i metadramatem. Artur Grabowski w swej najnowszej książce, poświęconej dramaturgii Bogusława Schaeffera, pisze:

Biorąc sobie teatr za temat i za materię, dramat czyni jawna swoją nadrzędność wobec teatru, swoją wobec niego prymarność, przez co, paradoksalnie, definiuje się w swojej niezależności od performansu - w swojej własnej performatywnej istocie. Teatr bowiem nie jest dramatowi potrzebny jako środowisko, w którym jedynie może on zaistnieć, jest mu on niezbędny jako uświadomiona teatralna konwencja, przywołana w przestrzeni literatury i za sprawą jej środków [...]. Dzięki sztukom metateatralnym dostrzegamy, że to dramat umożliwia teatr, a nie odwrotnie ${ }^{28}$.

Zatem mamy oto paradoksalną sytuację, gdy - zależnie od sposobu traktowania na scenie literatury - albo teatr wytwarza dramaty (,teksty dla teatru”), albo dramaty umożliwiaja teatr (,sztuki metateatralne”). Raz prymarny jest teatr, innym razem podstawowy okazuje się dramat. Raz dramat nie jest teatrowi potrzebny, kiedy indziej to teatr nie jest niezbędny dramatowi. Moim zdaniem kluczem do zrozumienia tych relacji jest,

${ }^{28}$ A. Grabowski, Prawdziwy Dramat Teatru. O metateatrze i metadramacie Bogustawa Schaeffera, Kraków 2017, s. 246. 
powtórzmy, stosunek sceny do literatury i literatury do sceny. Pomocna będzie tu kategoria performatywności.

Chciałabym zatem zaproponować czytelnikowi pewną zabawę w "splątanie”. Proszę w podanym akapicie zamienić określenie „teksty dla teatru” na „teatry dla tekstu”. Na ile przytoczony fragment zmienił znaczenie?

W tekstach dla teatru chodzi właśnie o ten aspekt - „dla teatru”, o pisanie ze świadomością medium, z trójwymiarowym wyobrażeniem zawartym nie w pisarskich didaskaliach, ale w zintegrowanej wizji scenicznej. Teksty dla teatru mają z reguły ten intermedialny, domagajaccy się scenicznej aktualizacji aspekt, mogą być zatem w lekturze bardziej wymagające niż regularne dramaty ${ }^{29}$.

W teatrach dla tekstu chodzi właśnie o ten aspekt - „dla tekstu”, o pisanie ze świadomością medium, z trójwymiarowym wyobrażeniem zawartym nie w pisarskich didaskaliach, ale jako w zintegrowanej wizji scenicznej. Teatry dla tekstu maja $\mathrm{z}$ reguły ten intermedialny, domagajacy się scenicznej aktualizacji aspekt, moga być zatem w lekturze bardziej wymagające niż regularne dramaty.

Skoro moga być „teksty dla teatru” to dlaczego nie moglibyśmy sobie wyobrazić istnienia „teatrów dla tekstu”? W zwrocie pierwszym podkreślona jest służebność tekstów wobec teatru, w zwrocie drugim sytuacja się odwraca - to różne teatry budowane sa po to, by służyć tekstom. W pierwszym przypadku teksty wchodzą na teatralną scenę, w drugim teatralna scena wchodzi do tekstu. Dramaturgiczne działania zmieniają i tekst (pod wpływem teatralizacji), i teatralną scenę (pod wpływem literatury). Teatr i literatura stają się na równi sztukami performatywnymi. Pisanie performatywne można uprawiać zarówno w teatrze, jak i na papierze. W literaturze oznaczać ono będzie aranżowanie pracy teatralnej na „scenie pisma”, $\mathrm{w}$ teatrze natomiast aranżowanie pracy tekstowej na scenie teatru, ,pisanie na scenie". Scena pisma i pisanie na scenie pozostają w chiazmatycznym zwarciu. Dramat i teatr splątują się.

\section{Dramat i teatr - sztuki splątane}

Literatura i teatr spotykają się ze sobą na gruncie sztuki, dodajmy: sztuki performatywnej. Nie wchodząc już w dalszą dyskusję, czy i na ile cała sztuka jest performatywna, wymienić by można szereg działań artystycznych i szerzej wszelkich czynności animacyjnych, przedsięwzięć kuratorskich, które sprowadzają się do tego, że proponowane zabiegi teatralizuja tekst literacki.

${ }^{29}$ J. Krakowska, dz. cyt., s. 9. 
Różne teatry są dla tekstu. Jednym z nich jest teatr rysunku, o którym pisał Andrzej Klimowski, jeden z opiekunów projektu studentów PJATK, dotyczacego wydania Gyubala Wahazara „Ilustrowanie książki nie odbiega aż tak bardzo od reżyserowania sztuki. [...] Chcąc dobrze wywiązać się z zadania [...] ilustrator musi odrzucić wszelkie rutynowe zachowania" ${ }^{30}$. Od rysunku pojętego tradycyjnie jako „ilustracja” świata przedstawionego (choć nie biernego, wpływającego przecież także na kształt i odczytywanie wydanego tekstu) już bardzo blisko do typografii, która jednak głębiej ingeruje w materię samego tekstu przekształcając samą linię pisma, stapiając się z nim w jedno; scenę(?), akt(?), didaskalia(?). Gdyby przyjrzeć się na przykład typografii didaskaliów Gyubala Wahazara, dodatkowo poruszonych podczas uruchomienia animacji, dostrzec można, że to nie jest żaden przekład ani adaptacja. Dramaty Witkacego, zachowując tożsamość, pokazały nowe sensy sztuk splątanych - na przykład informacja wyrażona w didaskaliach Witkacego, prosta informacja: „okien nie ma” podana jako „no windows”, powtórzona parokrotnie na bokach kwadratu wyznaczającego zarys pokoju, wydobywa element absurdalnego humoru, którym Witkacy operował zawsze znakomicie. Didaskalia Witkacego zaczęły być właśnie równoznaczne „z trójwymiarowym wyobrażeniem zawartym nie w pisarskich didaskaliach, ale jako w zintegrowanej wizji scenicznej" [korekta celowa AK]. Grafika i animacja wpisała teatralną scenę w tekst literacki. Można by mówić o dekonstrukcji jako przemieszczeniu, czy powtórzeniu i różnicy, a nawet także o architekturze tekstu. Przestrzenność, trójwymiarowość, nie pozostaja już zatem tylko domeną teatru, ale są kategoriami kształtującymi także literaturę (upada podział sztuk na czasowe i polowe, odżywa natomiast jako jedno z ważnych pojęć antybinarnych, pojęcie Bachtinowskiego chronotopu, a być może także Bachtinowska kategoria niewspółobecności). W dokonaniach studentów PJATK, skojarzenia z dokonaniami Derridiańskich zapisów, na przykład z Prawdy w malarstwie, okażą się nieuniknione (z tą tylko różnicą że Derrida nie dokonywał animacji swych tekstów...). Wzorem dla studentów PJATK był jednak nie Derrida, a Themersonowie. O dramaturgii projektów artystycznych Themersonów, co bardzo dziwi, napisano jednak mało ${ }^{31}$.

\footnotetext{
${ }^{30}$ A. Klimowski, O projekcie, [w:] S.I. Witkiewicz, Gyubal Wahazar..., s. 280.

${ }^{31}$ Por. na przykład E. Kraskowska, O dramatycznych $i$ „dramatopodobnych” utworach Stefana Themersona, [w:] Teatr i dramat polskiej emigracji 1939-1989, pod red. I. Kiec, D. Ratajczakowej, J. Wachowskiego, Poznań 1994, s. 160-166; T. Kubikowski, Semantyczna Wampuka, „Teatr” 1991, nr 10, s. 36; A. Dziadek, Themerson i Schwitters, „Teksty Drugie” 2006, nr 4, s. 91; A. Hejmej, Estetyka intermedialności Stefana Themersona: („St. Francis The Wolf of Gubbio or Brother Francis`Lamb Chops”) „Pamiętnik Literacki” 2011, nr 102/3, s. 57. Wymieniam jedynie parę klasycznych już dziś prac poruszajacych temat
} 
Dramaturg staje się zawodem uruchamiającym nieraz bardzo skomplikowane procesy wielokrotnego splątania literatury i teatru. Ani nie jest reżyserem, ani artystą teatru, ani krytykiem literackim/teatralnym; dramaturg to mistrz wytwarzania procesów performatywnych, dramaturg jest dramatografem - pracuje w materii literackiej i teatralnej równocześnie, jednej nadając cechy drugiej. Organizuje to, co w fizyce kwantowej nazywałoby się uruchomieniem aktów splątania cząstek. Wszystko, co dotyczy jednej czastki, obejmuje drugą. Dramat i teatr, należące do sztuk performatywnych, są takimi cząstkami w stanie splątania. Akty tego splątania aranżujemy podczas uczestnictwa w tworzeniu różnych dramatografii. Termin dramatografia wprowadziłam właśnie po to, aby podkreślić rolę pisma (linii zapisu nieopozycyjnego wobec rysunku) i równocześnie zaakcentować cechę jego charakteru, tj. sprzężenia z działaniem (odgrywanie utrwalonej historii, ruch zapisującej ręki i całego ciała), sprzężonego z dramatycznością ze względu na takie właśnie splątanie aktywności pisania nieopozycyjnej wobec rysunku, oraz działania dramaturgicznych technik we wszystkich dramaturgiach sztuki i życia. W tym oczywiście literatury, która - uznana za sztukę performatywna - określa, zawsze zmienne, sposoby „czynienia” słowem (ustanawiania światów możliwych) oraz „czynienia” słowa (stawania się słowa w splątaniu: jako pisma, jako obrazu, jako dźwięku). Dramaturg jest więc operatorem sceny tekstu (wyrażenie to celowo splątuje określenia budzące skojarzenia z różnymi sztukami, kolejno: filmem-operator, teatrem-scena, literatura-tekst), staje się zatem dramatografem (układa zapis pewnej dramaturgii).

Termin dramatografia pozwala na nieodwracalne splatanie porządków pisma (akt pisania) z porządkami dramatu (akt odgrywania). Powstajace w działaniu słowo uruchamia zwrotnie działanie, które znosi opozycje pisania jako operowania językiem i doświadczania świata. Dramatografia to opowieść o nas samych jako innych, którzy rozpoznajemy siebie we własnych aktach kreacji. Od jaskiniowych malowideł naskalnych ${ }^{32}$ po obrazy Jacksona Pollocka performatywnie stwarzamy świat, pozbawiony odniesienia; ubieramy w złudzenia realności to, co sami stwarzamy. Budujemy świat na sposób dramatyczny (jeśli dramat rozumieć jako działanie, ale też potocznie jako wydarzenie tragiczne). Zamknięci w swojej niepewności, skazani jesteśmy stale na możliwości wyborów, bez poznania konsekwencji wyborów

dramatu. Problem dramaturgii prac Themersonów zasługuje na szersze opracowanie, co zasygnalizowałam także w moim artykule poświęconym dramatografii. Chciałabym podjąć go przy innej okazji.

${ }^{32}$ Tu pragnę podziękować moim studentom, zwłaszcza antropologom z polonistyki w kontekstach kultury, którzy prowadzili ciekawe dyskusje podczas wieloletnich zajęć dotyczących doświadczenia performtywnego w sztukach wizualnych. 
niepodjętych. Dramat istnienia - który jest równocześnie jedynym możliwym światem i potencjalnym snem - staje się pułapka. Czy nie słyszeliśmy kiedyś już tego w Calderonowskim dramacie?...

\section{Literatura - sztuka performatywna ${ }^{33}$}

Oba człony dookreślające literaturę, czyli sztuka i performatywność, budza pytania, stale prowokując do dyskusji. To, że literatura jest sztuka, nie ulega wątpliwości, jak i fakt, że może być wyrażana nie tylko w słowach, ale i przyjmować postać różnych mediów (w znaczeniu, jakie nadawał temu uwikłaniu na przykład Werner Faulstich ${ }^{34}$ ) - jest dziś już niemal truizmem. Ale czy literatura jest performatywna? A jeśli tak, czy to oznacza, że każda sztuka jest performatywna? Czym zatem performatywność literatury różni się od performatywności teatru? ${ }^{35}$. Czy performatywność i teatralność się wykluczają? Czy literackość i teatralność muszą mieć wektory przeciwne? Czy i jak można mówić o doświadczeniu performatywnym dotyczącym sztuk wizualnych? Czym jest performatywność obrazu? Pytania najprostsze budzą najwięcej kontrowersji.

Performatywność literatury to problem sam w sobie skomplikowany i wcale nie tak jednoznaczny, jakby się z pozoru wydawało, zwłaszcza że samo pojęcie literatury jako „sztuki słowa” okazuje się coraz mniej znaczące, żeby nie powiedzieć - wręcz archiwalne. Do tych zagadnień wypadnie jeszcze powrócić. To oczywiście temat na osobną książkę. Tutaj podejmuję problem jedynie w kontekście proponowanej w artykule antybinarnej teorii dramatu. Akt splątania dramatu i teatru nieuchronnie prowadzi także do aktu splątania literatury ze scena, na koniec teorii ze sztuka. Cechą tych aktów czynię performatywność.

W ramach tego szkicu nie będę ani powtarzać przywoływanych wielokrotnie rozpraw, ani prezentować stanowisk autorów, należących już do klasyków, a wywodzacych się z różnych tradycji badawczych. Nie będę zatem zaczynać od pozycji, od których zwykle biora początek prace traktujące o zwrocie performatywnym, czyli - mówiąc nieco humorystycznym skrótem - od Austina „działającego słowami” ${ }^{36}$, od Isera z „apelatywną struktura

${ }^{33}$ Por. także A. Krajewska, Różewicza sztuki splatane. Interpretacja performatywna, „Przestrzenie Teorii” 2014, nr 21.

${ }^{34}$ W. Faulstich, dz. cyt.

${ }^{35}$ Por. także A. Grabowski, Dramatu-pisanie jako performans. Zeznanie sprawcy, [w:] Performans, performatywność, performer. Próby definicji i analizy krytyczne, pod red. E. Bal i W. Światkowskiej, Kraków 2013.

${ }^{36}$ J.L. Austin, Jak działać stowami, [w:] tegoż, Mówienie i poznawanie, przekł. B. Chwedeńczuk, Warszawa 1993. 
tekstów literackich" ${ }^{37}$, od Cullera analizującego tajemnicę przykładowego wiersza Roberta Frosta Sekret siedzi $i^{38}$, od Attridge`a „odgrywającego referencje” 39 , Derridy obiecującego nam za Paulem Cézanne'em „prawdę w malarstwie” ${ }^{40}$, Deleuze'a porzucającego „teatr przedstawienia na rzecz teatru powtórzenia” ${ }^{41}$, od Butler „, odgrywającej płeć”42, czy McKenzy'ego groźnie rozkazującego „performuj albo”... ${ }^{43}$. Chodzi mi raczej o uchwycenie tego momentu, który powstaje na styku dwóch dyscyplin: teatrologii i literaturoznawstwa, powodując, że zjawiska dotąd wiązane z literatura (dramat) i te odsyłające do teatru (przedstawienie) zaczynają przyglądać się sobie, wchodzić w relacje, przenikać wzajemnie, a na koniec stawać się „sztukami splątanymi”. Dzieje się to za sprawą performatywności, która wniosła podstawową zmianę myślenia o sztuce i o teorii w procesie przekształcania „tekstowego świata” w „świat splątany”. Działając na polu humanistyki, aranżujemy akt splątania i oto parametry jednej z cząstek przejmuje druga, niezależna, oddalona, a jednak ujawniająca jej cechy, pozostając z nią w stanie kwantowego splątania. Mamy oto dwie cząstki - jedna przyjmuje właściwości drugiej: ,,spektakl teatralny potraktować można jako dzieło literackie" ${ }^{44}$, albo odwrotnie dzieło literackie zobaczyć jako spektakl teatralny. Likwidujemy zatem kolejne opozycje, jak dramat-teatr, literatura-sztuka, literatura-medium, fikcja-prawda, teatrologia-literaturoznawstwo, medioznawstwo-literaturoznawstwo, sztuka-teoria etc.

$\mathrm{Na}$ początek przyjrzyjmy się zatem trzem wybranym ujęciom traktującym o performatywności literatury. Dwa pierwsze przykłady dotyczą wypowiedzi teatrologów, trzeci jest związany z perspektywą literaturoznawcza.

Przykład pierwszy. Oddajmy głos Erice Fischer-Lichte, która w swojej ostatnio przetłumaczonej i wydanej w Polsce książce Performatywność powołuje się na ustalenia grupy naukowej pracującej wspólnie nad projektem „Kultury performatywne”, pisząc, że jej członkowie dokonali rozróżnienia na

${ }^{37}$ W. Iser, Apelatywna struktura tekstów. Nieokreśloność jako warunek oddziatywania prozy literackiej, przeł. M. Łukasiewicz, „Pamiętnik Literacki” 1980, z. 1.

${ }^{38}$ J. Culler, Literatura $w$ teorii, przeł. M. Maryl, Kraków 2013.

${ }^{39}$ D. Attridge, Jednostkowość literatury, przeł. P. Mościcki, Kraków 2007.

${ }^{40}$ J. Derrida, Prawda w malarstwie, przekł. i posłowie M. Kwietniewska, Gdańsk 2003.

${ }^{41}$ G. Deleuze, Różnica i powtórzenie, przekł. B. Banasiak i K. Matuszewski, Warszawa 1997.

${ }^{42}$ J. Butler, Zapisy na ciele, wywrotowe odgrywanie, [w:] Teorie literatury XX wieku. Antologia, pod red. A. Burzyńskiej i M.P. Markowskiego, Kraków 2006.

${ }^{43}$ J. McKenzy, Performuj albo... Od dyscypliny do performansu, wstęp i przekł. T. Kubikowski, Kraków 2011.

${ }^{44}$ Zdanie jest parafrazą fragmentu wypowiedzi Krzysztofa Kozłowskiego z przedmowy do książki Faulsticha: „film fabularny jako dzieło literackie nie powinien przecież brzmieć obecnie aż tak obco" (s. XXX). 
strukturalną i funkcjonalną performatywność tekstów literackich ${ }^{45}$. Strukturalna performatywność miałaby kierować uwagę na dyskurs i narrację, na pośredniczenie między tekstem a czytającym, zakładać rodzaj „dwugłosowości” mówienia i pokazywania (czytelnik słucha tego, co tekst mówi i równocześnie dostrzega, jak tekst realizuje to, o czym mówi). Fischer-Lichte, powołując się zwłaszcza na ustalenia Sybille Krämer, wskazuje na aspekty performatywności strukturalnej tekstów jak ,inscenizacja” i „przedstawienie”, które odnoszą się „do takich operacji retorycznych, dzięki którym tekst literacki symuluje efekty języka mówionego" ${ }^{46}$, a do których należą różne strategie autoreferencjalne (jak choćby pozorowana rozmowa między narratorem a czytelnikiem) i dalej traktuje o napięciu między trybem konstatującym a performatywnym, które zmienia „tekst w metaforyczną scenę, na której jego własny dyskurs staje się przedmiotem przedstawienia" ${ }^{47}$. Powołując się z kolei na pracę zbiorowa Text und Performativität z 2011 roku, podkreśla, że teksty literackie potrafią sugerować obecność poprzez takie strategie tekstowe, jak „fingowanie języka mówionego, kierowanie spojrzeniem i wizualizację, showing zamiast telling i unaocznianie związków między wydarzeniami”" ${ }^{48}$. Fischer-Lichte, referujac kolejna cechę performatywności strukturalnej, zwraca też uwagę na oddziaływanie literatury na czytelnika, gdy „w procesie lektury pojawiają się w nim niezamierzone i nieoczekiwane wyobrażenia, wspomnienia, skojarzenia i sensy, których struktura tekstu ani nie podpowiada ani nie narzuca”, które są wynikiem „relacji między elementami tekstu i własnymi doświadczeniami [...]. Skoro tekst nie ma na ten proces żadnego istotnego wpływu, otwiera się on na rozmaite ambiwalencje" ${ }^{49}$. Natomiast performatywność funkcjonalna nastawiona jest na wyzwalanie sił oddziaływania na odbiorcę, czytelnika, sił zależnych od strategii retorycznych i kontekstów kulturowych, a także, może nawet przede wszystkim, wpływu na „cyrkulację tekstów w społeczeństwie, dzięki której wytwory kultury pisanej stają się częścią praktyk kulturowych" ${ }^{50}$. $\mathrm{Na}$ koniec króciutki fragment rozdziału poświęcony jest problemowi „tak zwanej adaptacji” ${ }^{51}$, na przykład filmowej, która uważana jest już za inne dzieło wyrażone za pomocą odmiennych strategii i zabiegów retorycznych, a nie za interpretację na przykład danej, powiedzmy przykładowo, powieści.

${ }^{45}$ E. Fischer-Lichte, Performatywność, tłum. M. Borowski, M. Sugiera, Kraków 2018, s.184.

${ }^{46}$ Tamże, s. 187.

${ }^{47}$ Tamże, s. 187.

${ }^{48}$ Tamże, s. 187.

${ }^{49}$ Tamże, s. 188.

${ }^{50}$ Tamże, s. 185.

${ }^{51}$ Tamże, s. 193. 
Przykład drugi. W.B. Worthen we wstępie do swojej książki pod znamiennym tytułem Dramat: między literaturq a przedstawieniem pisze: „to propozycja takiej lektury dramatu, która bierze pod uwagę dialektyczne napięcie między jego tożsamością literacką a performatywną"52. I zaraz dalej czytamy „Przyjrzę się temu, jak odzwierciedla on [dramat - AK] spotkanie tekstu jako przedmiotu (książki) i realizacji na scenie; spotkanie tekstu i ucieleśnienia; tekstu i przestrzeni sceny. Jak sztuki określają warunki własnego użycia, rzucając wyzwanie binarnej opozycji między literaturą a przedstawieniem, która leży u podstaw dominujących modeli teatru dramatycznego. [...]" ${ }^{53}$. Worthen rozważa na bardzo przekonującym przykładzie dramatów Szekspira różne postacie tych sztuk, próbując uchwycić historycznie zmienna „tożsamość dramatu jako interfejsu między pismem a technologiami przedstawienia” ${ }^{4}$. Kolejne przestrojenia nazywa: „Szekspir 1.0, czyli teksty jako materiał do przedstawień, Szekspir 2.0, czyli teksty w postaci drukowanej książki, Szekspir 3.0, czyli teksty w postaci cyfrowej. „Proces zmiany sztuk Szekspira z towaru teatralnego w literacki dowodzi, że podwójna tożsamość dramatu to kwestia historyczna i kulturowa. Dziś uważa się, że Szekspir przekroczył granice między literaturą a teatrem" ${ }^{55}$.

Przykład trzeci. J. Hillis Miller w książce O literaturze pisze: „Literatura to użycie słów, które za pomoca czytelników sprawia, że pewne rzeczy się dzieją"56. Ale też literatura strzeże swych tajemnic. Poznając dzieje Odyseusza, mamy jedynie relacje Homera, a nie słyszymy samej pieśni Syren. „Chcielibyśmy dokładnie wiedzieć, jak brzmiał syreni śpiew. [...] Wiedza ta mogłaby okazać się zgubna w skutkach” ${ }^{57}$. „Literaturę można zatem określić jako dziwne użycie słów, owo użycie odsyła [refer] do rzeczy, ludzi i zdarzeń, o których niemożliwością jest wiedzieć, czy aby nie wiodą gdzieś utajonego istnienia"58.

Co zatem wynika z wybranych tu przykładowo spośród prac teatrologicznych i literaturoznawczych przykładów definiowania performatywności literatury? Przede wszystkim zaczynają się one spotykać ze sobą (o co $\mathrm{w}$ tradycyjnej teatrologii było raczej trudno $\left.{ }^{59}\right)$.

${ }^{52}$ W.B. Worthen, Dramat - między literatura a przedstawieniem, tłum. M. Borowski, M. Sugiera, Kraków 3013, s. 19.

${ }^{53}$ Tamże, s. 21.

${ }^{54}$ Tamże, s. 38/39.

${ }_{55}$ Tamże, s. 21.

${ }^{56}$ J.H. Miller, O literaturze, tłum. K. Hoffmann, Poznań 2014, s. 29.

${ }^{57}$ Tamże, s. 45.

${ }^{58}$ Tamże, s. 49.

${ }^{59}$ Por. J. Wachowski, Performans, Gdańsk, 2011, s. 322 oraz tegoż, Performer, performans, performatywność, czyli o miejscu performatyki $w$ badaniach teatrologicznych, [w:] 
Spora zasługa Eriki Fischer-Lichte jest wprowadzenie do dyskursu teatrologicznego refleksji literaturoznawczej - głównie z obszaru niemieckojęzycznego. Rozdział poświęcony literaturze oraz sztukom wizualnym w pewnym stopniu otwiera teatrologię niejako od wewnątrz, pozostawiając nadal główny nurt dyskursu w jej ramach.

Autorka książek Estetyka performatywna oraz Performatywność w przypadku literatury rozróżnia performatywność strukturalną i funkcjonalna. Moim zdaniem te podziały sa nietrafne. Zapewne na przekór intencji Fischer-Lichte, która w wielu miejscach świetnie analizuje antybinarne zjawiska w sztuce teatru (por. interpretację spektaklu Elektry Sofoklesa na scenie Kleines Theater w Berlinie w 1903 roku, premiery przygotowanej przez Maxa Reinhardta, w którym przezwyciężona została „binarna opozycja między kulturami skoncentrowanymi wokół ciała i wokół tekstu”"60, a także w perspektywie zasad procesu percepcji („Dychotomiczne pary pojęć służą nie tylko jako narzędzia poznania i opisu rzeczywistości, ale także jako zasady regulujące nasze działania i zachowania. Nic więc dziwnego, że ich destabilizacja pociaga za sobą rozregulowanie mechanizmu postrzegania świata siebie i obcych, co podważa reguły i normy, kierujące naszym zachowaniem"61). Niestety, poprzez podział performatywności na strukturalną i funkcjonalna - odżywa tradycyjne odniesienie binarne - ku strukturze tekstu literackiego i ku kulturze performansu społecznego. Moim zdaniem nie da się mówić ani o strukturze, ani o funkcji, jeśli równocześnie przyjmuje się procesualne ujęcie wydarzania się sztuki i nie utożsamia się literatury z semiologicznie rozumianym tekstem. Może jednak to tylko kwestia ciążenia dawnego języka opisu zjawisk nieprzydatnego do pokazania znoszacej binarność performatywności? Mam wrażenie, że odzywa się w tym podziale myślenie o dwóch zwykle w teatrologii separowanych typach performatywności: rozumianej po prostu jako działanie (w tym także w aktach mowy) i jako sprawczość (efekty przekształcające realna, społeczną rzeczywistość). Sprawa tekstu (rozważana w książce Estetyka performatywności w kontekście kultury, która widziana jako tekst została zastapiona wizją kultury jako performansu) wtedy pozostaje na boku, a raz podjęta odsyła w pierwszym odruchu do, już w tym kontekście anachronicznego, pojęcia struktury. Do kwestii struktury, funkcji i tekstu wypadnie jeszcze powrócić w kolejnym podrozdziale.

W analizach niemieckiej teatrolog przewijają się też myśli, które wywołują we mnie ciagi skojarzeń ze znanymi rozpoznaniami z przeszłości.

Performans, performatywność, performer. Próba definicji i analizy krytyczne, pod red. E. Bal i W. Światkowskiej, Kraków 2013.

${ }^{60}$ E. Fischer-Lichte, Performatywność..., s. 18.

${ }^{61}$ Tamże, s. 92. 
Przykładowo, jeśli Fischer-Lichte pisze o „operacjach retorycznych, dzięki którym tekst literacki symuluje efekty języka mówionego" ${ }^{62}$, przypomina mi się momentalnie Michaił Bachtin i jego teoria "gatunków mowy”, ale też koncepcja „mimetyzmu formalnego”, sformułowana swego czasu przez Michała Głowińskiego. Pamiętam, gdy jeszcze jako asystentka prowadziłam zajęcia z poetyki i poleciłam studentom przepisywanie niektórych opowiadań Sławomira Mrożka na dramaty, obserwowaliśmy, jak postać rodziła się w prozie poprzez głos, poprzez mowę osobniczą, wciskając się mimochodem w opowiadanie, powodując przekształcenie narracji w mowę pozornie zależna, wyłaniała się, starała zaistnieć w strzępie zwrotu, w niedopowiedzianym równoważniku zdania, w charakterystycznym frazeologizmie wtopionym w mowę narratora, a w końcu uwolniona od jej reguł (poprzez nasz zabieg dekompozycji), zaczynała już mówić w pełni swoim głosem. Odwracaliśmy zatem klasyczną interpretację mowy pozornie zależnej jako tej, w której mowa narratora wchłania cechy mowy bohaterów i pokazywaliśmy, że to może raczej postacie, chcąc zaistnieć w świadomości odbiorcy jako niezależne, próbują wedrzeć się w ograniczająca ich suwerenny byt - mowę narratora. Stawał się dramat, czyli swoboda panowania wolnych głosów. Pamiętam, czytaliśmy potem na zajęciach fragment z Retoryki Jerzego Ziomka dotyczący „genusów”, jak humorystycznie mawiali studenci, czyli podziału genera dicendi na: genus enarrativum, genus mimeticum/dramaticum, genus mixtum. Wywodzenie powstania dramatu z uwolnionej od wszelkiej nadrzędności i zależności od mowy narratora - mowy postaci, było pierwszą lekcją... wolności, dramatycznej wolności słowa. Można wtedy było dostrzegać także, jak działa ironia, jak mowa może kompromitować lub uwiarygodniać, jak działa moc perswazyjna, jakie są uzależnienia mowy własnej od mowy cudzej itd., itp. Nie uruchamiam wspomnień z moich doświadczeń dydaktycznych dla nich samych - chcę poprzez ten przykład zwrócić uwagę na przydatność rozmaitych teorii dramatu, które, zapomniane w rzekomo postdramatycznej utopii, powracają przy zupełnie nieoczekiwanych okazjach. Czyżby moi dawni studenci uprawiali już lekturę performatywną? Przygarnialiśmy wtedy różne koncepcje dramatu, nie odrzucając żadnej. Powtórzę dziś swą własną metaforę Proteuszowej natury dramatu, który ma moc zmiany, jest tym, czym chcemy go zobaczyć (raz forma mowy, innym razem uobecnieniem postaci, zwyczajowo akcja, zdarzeniem, ale też aktem powołania fikcyjnego świata, który staje się na swój sposób realny poprzez zabiegi uwierzytelniające pozór itp.). Dramatyczności mowy, sceniczności literatury, aktywności jako działania odbiorcy nie dało się tutaj rozdzielić.

${ }^{62}$ Tamże, s. 187. 
Teoria dramatu, wiążąca początki gatunku z formami podawczymi oraz gatunkami mowy, powraca dzisiaj nieraz w zadziwiających kontekstach. Teatrologia, majaca za przedmiot badań konkret w postaci przedstawienia na scenie, stale chce się pozbyć dramatu, czyniąc to nieraz na sprzeczne sposoby (a to chce popchnać go w objęcia literatury, czyli wyrzucić z teatru, a to znów odwrotnie, wyrywać go z jej pęt, czyli uwolnić od tekstowości). Sa jednak i odmienne podejścia do dramatu. Wybrałam specjalnie przykład pisarstwa Artura Grabowskiego, autora, który prezentuje niekonwencjonalne myślenie teatrologiczne (również wykorzystywane w praktyce teatralnej), łącząc je z refleksją literaturoznawczą. Polemizując z teorią Lehmanna, Grabowski słusznie pokazuje, jak w sytuacji, gdy dramaturg przejął całkowita „władzę nad dramatopisarzem, którego redukuje do roli dostarczyciela materiału słownego, i nad reżyserem, którego sprowadza do roli wykonawcy swojego projektu, stając się faktycznie [...] organizatorem performatyzacji obejmującej tekst, scenę i widownię"63, dramat może się obronić i odzyskać tożsamość. „Dramat w takim performansie nie staje się na powrót opowieścią o czymś, staje się samym wypowiadaniem [...] Podporządkowanie działania mówieniu nie może ograniczać funkcji wypowiedzi do budowania inscenizacji, musi uszanować je jako znaczące źródłowo. Performans teatralny staje się wówczas praktykowaniem literatury, sama literatura zaś uzyskuje świadomość, że zawsze była sztuka performatywna”"64. Grabowski dodaje „dramat odzyskał autonomię, uzyskał estetyczną podmiotowość i ponownie stał się równorzędnym partnerem teatru" ${ }^{65}$. Czyżby, znów paradoksalnie, performatywność teatru jako sztuki performansu odsłoniła performatywność dramatu jako performatywnej literatury?

Kolejną kwestia, ulubioną zwłaszcza przez teatrologów, jest utożsamianie performatywności ze sprawczością. Dla mnie ważniejsze jest zobaczenie, jak staje się literatura. Performatywność wiązałabym z wytwarzaniem literackiego działania. Sprawczość literatury to przede wszystkim ustanawianie świata, w którym realność i fikcyjność pozostają w stanie splątania. Sprawczość literatury rozumiana częściej jako oddziaływanie na odbiorcę i odpowiedzialność za jego przekształcenie, poruszenie emocjami, wpływ na reakcje związane z doznaniami somatycznymi - ma stronę przeciwna - odbiorca jest równocześnie twórcą performansu. Tu przebijają wątki dobrze znane w literaturoznawstwie (zarówno Ingardenowski problemem z miejscami niedookreślenia, z konkretyzacją i aktualizacja, jak i Derridiańskie błędne czytanie czy sekret). Nie o rozszerzenia refleksji tu chodzi, ale o zauważenie związku literatury (dramatu) z teatrem (teatralnościa, insceniza-

\footnotetext{
${ }^{63}$ A. Grabowski, Dramatu-pisanie jako performans..., s. 98.

${ }^{64}$ Tamże, s. 99.

${ }^{65}$ Tamże, s. 99.
} 
cja, przedstawieniem, scena) poprzez kategorię performatywności. Jak już pisałam, nie dzieliłabym jednak performatywności poprzez wyróżnianie jej typów, a już na pewno nie nazywałabym jej, podążając za Fischer-Lichte, strukturalną i funkcjonalna. Określenia te znoszą jakby ideę samej performatywności, która podważa właśnie sposób widzenia tekstu jako struktury! Nie brzmi też dobrze określenie performatywności w związku z funkcjonalnościa, z tej prostej przyczyny, że sprawczość nie zawsze oznacza funkcjonalność. Sprawczość literatury wcale nie musi dotyczyć realnych działań w realnym świecie, jak (to jeden z „dyżurnych” przykładów!) fali samobójstw po ukazaniu się Cierpień mtodego Wertera Goethego. Nie chodzi też i o to, żeby, jak w przypadku Dziadów w reżyserii Dejmka w 1968 roku (to kolejny „dyżurny” przykład!) sztuka uruchomiła bunt społeczny. Literatura niekiedy wielokrotnie (i różnie!) kształtuje nasze życie. Od noszenia swego czasu przez młode dziewczyny, wykonywanych samodzielnie na szydełku kapelusików, które lubiła bohaterka z kultowego filmu Love story, po wzruszenie i łzy zakładające empatyczne odniesienie do postaci z melodramatu. Jednak taka sprawczość dla mnie nie jest performatywna. Myślę, że sprawczość literatury polega na tym, że zmienia nasze przyzwyczajenia w odbiorze świata, poprzez budowanie odpowiedniej dramaturgii tworzy dyskurs, zaprzeczający bytom, które opisuje, stawiając nas w sytuacji odbioru anamorficznego. Nie mamy pewności, ale widzimy to, czego nigdy byśmy pewnie nie dostrzegli poza światem sztuki, jak w malarstwie ulegamy złudzeniom, które bierzemy za prawdę. Nie ma niebieskich jabłek, ale można niebieskie jabłka zobaczyć po doświadczeniach zdobytych podczas percepcji malarstwa. Koty wielokrotnie przebiegają zakurzone drogi, ale tylko w świecie poetyckiego języka Leśmianowski „kot przebiega w kurz drogę”. Dzieje się tak wyłącznie w świecie, w którym i kot, i kurz, i przebieganie podlegaja „,splątaniu”. Literatura znosi przedział między językiem a światem. Język sztuki jest $\mathrm{w}$ swej funkcji performatywny $\mathrm{w}$ znaczeniu powoływania do istnienia rzeczywistości, która nie ma żadnego pierwotnego, uprzedniego odniesienia, przedustanowienia. Czyni to w procesie opisywania hipotetycznego świata, który równocześnie w tym dyskursie powołuje do istnienia. Buduje dyskurs performatywny wytwarzający światy, których wcześniej nie było (ale pewności, czy gdzieś nie egzystuja wcale nie mamy). Między językiem a światem nie istnieje zatem przepaść, język równocześnie wytwarza świat i jest jego jedynym odniesieniem. Stąd słowa padające ze sceny często odbierane sa dwuznacznie (jako fikcjonalne, ale równocześnie prawdziwe) i budzą u widzów poznawczy dysonans (między naiwnym utożsamieniem a odrzucającym dystansem). A zatem performatywność w przypadku języka sztuki nie oznaczałaby chęci realizacji szczytnego celu „odpowiednie dać rzeczy słowo”, ale działania powodującego, żeby odpowiednim słowem powołać rzeczy do 
istnienia. Konsekwencje z tak pojmowanej performatywności dotyczą także zmiany patrzenia na istotę aktorstwa. Aktor nie odgrywa postaci, ale aktor ja stwarza. Jak teatr nie wystawia dramatu, ale wytwarza jedna z jego postaci. Aby zdarzenie mogło zajść, potrzebne jest działanie iteracyjne, powtórzenie w wymiarze Derridiańskiej cytowalności.

Dlatego tak bliska jest mi koncepcja J. Hillisa Millera - literatura sprawiła w słowach, że pozostaję pod urokiem sekretu - wiem, że Syreny nie istnieją, ale równocześnie wcale nie jestem tego taka pewna; wiem, że gdybym się mogła przekonać, słysząc ich prawdziwy śpiew, sama przestałabym istnieć i niczego z tą wiedzą nie byłabym już w stanie zrobić. Literatura jest fascynująca, ale literatura jest też niebezpieczna. Od czasu poznania przygód Odyseusza wiemy, że Syreny istnieją naprawdę i stale wabią nas obietnicą najpiękniejszej pieśni.

Zatem funkcjonalność buduje określone fakty - performatywność budując fakty, równocześnie je podważa, prowadząc na manowce, bywa też - żeby tak rzec - pustą funkcjonalnościa, a nawet całkowitym jej zaprzeczeniem. Literatura jest performatywna, bo jest jedynie śladem pisma. Literatura jest performatywna właśnie dlatego, że jest niefunkcjonalna.

Z kolei refleksja W.B. Worthena (także próbująca łączyć punkty widzenia teatrologów, performatyków i literaturoznawców) jest bardzo ciekawa, ważną próbą złamania rygorystycznego przeciwstawienia dramatu teatrowi opisana poprzez metodę działania interfejsu, czyli stanu gotowości do rozmaitych przełączeń, ale także realizacji idei powtórzenia oraz przyjęcia koncepcji tekstu wywiedzionej z refleksji Derridy, zwłaszcza klasycznych fragmentów o Artaudzie (brakuje odwołań do rozdziału o Freudzie). Chciałabym jednak jeszcze podkreślić, że dla mnie nie sa przeciwstawieniem tożsamość literacka a performatywna, nie uważam też, by „performatyka uparcie opisuje[ywała] teatr dramatyczny jako swego potężnego przeciwnika" ${ }^{6}$. Zdanie to jest prawdziwe tylko w przypadku tych performatyków, często mających teatrologiczne korzenie, dla których literatura nie ma charakteru performatywnego, znacznie rzadziej odnosi się do performatyków zorientowanych literaturoznawczo, którzy swego czasu „przerobili” dekonstrukcję i „zwrot performatywny”. Moim zdaniem nie oddaje też dobrze natury procesu performatywnego stosowanie pojęcia dialektyki, rozumianej tu jako stwarzanie obszaru „pomiędzy” (wydaje się, że wykroczyliśmy już poza obszary „pomiędzy”, badając pola przenikania, zaskoczeń, wahań, „współobecności”), a także traktowanie literaturoznawtwa i performatyki osobno, niekiedy jako przeciwstawnych. Literaturoznawstwo też jednak bywa performatywne!

${ }^{66}$ W.B. Worthen, dz. cyt., s. 160. 


\section{Performatywność sztuki}

Sytuację dramatu i teatru trzeba już dziś rozważać w szerszym niż tylko literackim i teatralnym kontekście, tj. w odniesieniu do współczesnego rozumienia pojęcia sztuki. Z czasem zmieniło się bowiem nasze myślenie o sztuce rozumianej jako zbiór artefaktów, przedmiotów umieszczonych w muzealnej gablocie. Czy można jeszcze posługiwać się tradycyjnym podziałem sztuk, gdy zaczęły one ulegać filiacjom i, zacierając granice między soba, stawać się coraz częściej sztukami hybrydowymi (jak awangardowe typografie Themersonów, jak cinemagraphs Jamy Back), gdy pokonały bariery dzielące je od nie-sztuki, zatarły granice kultury wysokoartystycznej i popularnej (jak uznane za osiagnięcia literatury teksty piosenek Boba Dylana czy Kory, jak slam łączący poetykę wiersza z techniką stand-up), a także zaczęły istnieć $\mathrm{w}$ postaciach zależnych od interakcji z różnymi mediami (kiedy stało się jasne, że dzieło nie ma postaci kanonicznej, że nie tylko dzieła Szekspira opisane przez Worthena jako Szekspir 1.0 (sceniczny) 2.0 (drukowany), 3.0 (cyfrowy) - egzystuja w wielu postaciach. To samo zjawisko pokazuje z kolei Faulstich na przykładzie Obcego pasażera Nostromo - dzieło istnieje niemal równocześnie i równoprawnie jako film, książka, komiks - oraz na przykładzie wielu wersji Wojny światów - słynnej powieści Herberta George'a Wellsa z 1897 roku, słuchowiska Orsona Wellesa z 1938 roku, ale i filmu fabularnego z 1953/1954 roku Byrona Haskina, czy spektaklu telewizyjnego Josepha Sargenta ${ }^{67}$. W końcu, jak dowodzi na gruncie estetyki Artur C. Danto, diagnozując sztukę „po końcu sztuki”68, stało się możliwe wpływanie na przeszłość, gdy repertuar kształtuje archiwum (jak w pracach Davida Reada zmieniającego kadr w filmie Alfreda Hitchcocka Zawrót głowy, umieszczając w nim swój obraz). Jest jeszcze jedna sprawa dotycząca sztuki, a mianowicie dostrzeżenie, że teksty naukowe, zwłaszcza wyrastające z nurtów dekonstrukcji, maja swoje korzenie w działaniach artystycznych (jak na przykład plastyczno-teatralny rodowód ujawniaja pisma Jacques `a Derridy, które opisałam w 2005 roku w kontekście estetyki performatywnej ${ }^{69}$ między innymi jako sceno-grafie, a dziś nazwałabym je wręcz dramatografiami). Scena pisma nie jest więc metafora - rozgrywa się $\mathrm{w}$ niej swoista typografia i dramatografia tekstu zwiazzana $\mathrm{z}$ wykonaniem.

Nie dziwi zatem, że wszystkie te kategorie, które długo określały sposób mówienia i pisania o dramacie i teatrze, tj. adaptacja, przekład, przekład

${ }^{67}$ W. Faulstich, dz. cyt., s. IX (przedmowa K. Kozłowskiego).

${ }^{68}$ A.C. Danto, Po końcu sztuki. Sztuka wspótczesna i zatarcie się granic tradycji, przekł. M. Salwa, Kraków 2013.

${ }^{69}$ A. Krajewska, Dekonstrukcja jako problem estetyki (na przykładzie dramatycznego dyskursu Jacques'a Derridy), „Przestrzenie Teorii” 2006, nr 6. 
intersemiotyczny, interpretacja, postać kanoniczna dzieła, musiały upaść i stać się bezużyteczne jako narzędzia analizy i diagnoz stawianych współczesnej sztuce przy użyciu metodologii opartych na myśleniu opozycjami. Wobec tych wszystkich procesów sprawiających, że sztuka nie jest już dłużej utożsamiana $\mathrm{z}$ artefaktem, ale rozwija się procesualnie jako zdarzenie, oczywiste stało się i to, że jej badanie domaga się podejść antybinarnych, takich jak iteracja, performatywność, splątanie.

$\mathrm{Na}$ drodze dojścia do myślenia o dramacie i teatrze jako sztuce splątanej, jako o obszarze pewnych działań w obrębie, jakby powiedział Witkacy: „jedności w wielości”, wymienić trzeba jeszcze i ten punkt odniesienia, jakim była Wagnerowska idea Gesamtkunstwerk, wyrażana w projekcie dramatu muzycznego, a potem też koncepcja niemieckiego twórcy znana jako dramaturgia opery. To, co było oczywiste w kulturach Dalekiego Wschodu, inaczej (ale i pod pewnymi względami także podobnie) rozwijało się w kulturach zachodniej Europy. W japońskim teatrze kabuki oraz bunraku antybinarna estetyka wyrastała jednak z zupełnie innego światopoglądu estetyczno-religijno-kulturowego. Dramaturgia opery Wagnera i praktyka teatralna kabuki sa mimo to ciekawymi lustrami europejskiej i japońskiej dramaturgicznej teorii sztuki i takiejż wizji kultury. Ciekawym przykładem współczesnego zmieszania porządków różnych sztuk jest też japońska manga (rodzaj komiksu) i anime (rodzaj animowanego filmu na podstawie mangi), uzyskująca teatralne przedłużenie w popisach fanów (nie aktorów!), którzy sami szyją kostiumy, przygotowują rekwizyty i wcielają się w swoich bohaterów, by wystapić na przykład podczas targów mangi, a po drodze jeszcze złożyć papierowe teatrzyki (należące do sztuki origami) opracowane na podstawie mangi. Granice komiksu, powieści graficznej, filmowej animacji, plastycznych i teatralnych przedstawień zacierają się wtedy zupełnie (na przykład postacie „przechodzą" z mangi do anime, wyłaniają się z papierowych układów teatrzyków origami, ucieleśniają się poprzez swoich fanów podczas targów mangi tworząc fanowski ruch kulturowy. Czyż nie inaczej dzieje się w sztukach Witkacego, gdy niektóre postacie przechodzą z utworu do utworu, dyskutują z twórca, który powołuje się na ich nieistniejące traktaty naukowe, pojawiają się też na obrazach itp. Mieke Bal, stawiając diagnozę o głębokich filiacjach nauki ze sztuką napisała: ,[...] oba znaczenia performatywu - teatralne, jako wykonania, i społeczne, jako performatywności - sa kluczem do tego, co kulturowe w analizie kulturowej jo".

Wraz z przemianami w sztuce, na scenie obserwujemy tworzenie nowocześnie rozumianego tekstu wielkiego dramatu, który ujawnia na naszych

${ }^{70}$ M. Bal, Wędrujace pojęcia w naukach humanistycznych, przeł. M. Bucholc, Warszawa 2012, s. 105. 
oczach akt swojego powstawania, prowokując do działań określanych często jako rekonstrukcja, reaktywacja, lub traktowanych jako przekształcenia zmieniajace archiwum poprzez repertuar. „Ponieważ literackość jakiegokolwiek tekstu może zawsze ujawnić się w przyszłości, jeśli nie stało się tak w przeszłości, jest on ciałem bez określonych granic"71. Doprecyzowując sens tego słusznego przekonania Dereka Attridge’a, posłużmy się refleksją Jacques'a Derridy:

Archiwum nigdy nie zostanie zamknięte, albowiem archiwista wciąż wytwarza archiwum, które otwiera się na przyszłość.

W jaki sposób nietrudno możemy poddać refleksji to nieuchronne powtórzenie, ogólne powtórzenie w jego związku z pamięcią i archiwum? Nietrudno zinterpretować konieczność takiego związku, przynajmniej, kiedy łączymy archiwum - bo zwykle jesteśmy skłonni to robić - z powtórzeniem oraz z powtórzeniem przeszłości. Chodzi tu jednak o przyszłość i o archiwum jako nieredukowalne doświadczenie przyszłości $^{72}$.

Komentarz Derridy do myślenia Freuda wykracza poza wasko rozumiana „zmianę”, on otwiera archiwum i wyprowadza go w różne kierunki: ku pamięci, ku wirtualności, ku przyszłości etc. etc. Pamiętając o tych szerokich perspektywach stwarzanego ku przyszłości archiwum, wróćmy ze sceny freudowskiego dyskursu na scenę teatralną.

Nie musi to oznaczać tylko reaktywacji teatralnych, ale także może dotyczyć na przykład serii nowych wydań książkowych (na przykład „kolorowego Różewicza”, jak potocznie mówi się o wydaniu niebieskim i serii czerwonej, a także pomarańczowym, od koloru teczki zawierajaccej reprint Kartoteki). Co dzieje się na przykład z twórczością Juliusza Słowackiego, który poprzez nowe wydania (na przykład Jacka Brzozowskiego, Zbigniewa Przychodniaka czy Marka Troczyńskiego) odsłania coraz to inną twarz? Wydanie tekstu, tak samo jak spektakl, może być działaniem dramaturgicznym przekształcającym materiał wyjściowy, nadając mu nową jakość (nie tylko poprzez zmianę kontekstu, ale zmianę samego oblicza medialności tekstu). Dlatego te dwa, przytoczone przeze mnie na początku artykułu, przykłady spektaklu Klaty i dramatu Witkacego - operują tradycyjnym punktem wyjścia, czyli znanym tekstem literackim, wydanym drukiem, które to teksty wprowadzone zostały w pole performatywnych działań i pokazały zupełnie inne oblicze. Scena interaktywnego projektu (Witkacy) czy scena teatralna z prompterami (Wielki Fryderyk) uruchomiła nową sytuację anamorficznego odbioru, ujawniając sens tekstu jako pola możliwości, niekoniecznie determi-

${ }^{71}$ D. Attridge, dz. cyt., s. 91.

${ }^{72}$ J. Derrida, Gorqczka archiwum. Impresja freudowska, przeł. J. Momro, Warszawa 2016, s. 103. 
nującego konieczność jednoznacznego wskazania preferencji. Antybinarna estetyka pozwala bowiem zmienić nasze sposoby poznawania świata i uznać możliwość istnienia równoczesności, symultaniczności, anamorficzność jako realne i równoprawne widzenie i doznawanie świata. W kulturze zachodniej, w której dominuje myślenie dualne, takie przejście, taka zmiana optyki wydają się bardzo trudne do przyjęcia. Ilustruje to między innymi traktowanie pojęć należących do porządków sztuki. Wyraźnie widać to w historii dramatu i teatru.

Może zatem pora, proponując rozszerzenie pola obserwacji, czyli - zobaczenie dramatu w kontekście sztuki - wrócić do literatury i rozbroić dość niebezpieczny stereotyp mówiący o konieczności uwolnienia dramatu od literatury w celu zapobieżenia najgorszego, co może go spotkać, czyli wpisania w pojęcie tekstu odczytywanego na „modłę literaturoznawczą"? Zafascynowani teatrem teatrolodzy, jak Lehmann, nie dostrzegają na ogół zmian w istocie samej literatury, która już dawno przestała być tylko „,sztuką słowa", która sama uległa daleko idącemu procesowi dramatyzacji. Dramaturg jest także obecny w literaturze!

Moja refleksja nie będzie jednak dotyczyła tego, co narzucałoby się z cała oczywistością już za pierwszym skojarzeniem, czyli problemu medialności (na przykład funkcjonowania literatury w sieci, związków sztuki z Internetem, rzeczywistością wirtualną itp.), powodującej powstawanie nowej sztuki, prowadzącej do zmiany pojęcia literatury ${ }^{73}$. Hipertekst, liberatura, dramaty interaktywne itp. eksperymenty wyznaczyły już dawno nowe drogi rozwoju sztuki, w której, jak uważam, dramatyczność stała się podstawa. Ani też nie odniosę się w tym szkicu do problemu budowania różnych scen dla literatury, na przykład pomnika wiersza, wiersza jako zapisu na murze, wiersza przedstawionego jako obraz, a nawet pomnika języka itp.

Relacje różnych sztuk widzę zupełnie inaczej, odmiennie od tego, jak głosiły na przykład koncepcje ich korespondencji czy nawet idea syntezy, więc dlatego wolałabym już nie mówić o podziałach, ale o sztuce, a tu szczególnie o literaturze, w kategoriach performatywności. Proponowałabym przede wszystkim zrezygnować z wszelkich prób ustanawiania sztywnych podziałów typologicznych sztuk. Problem, czy cała sztuka jest performatywna, przeformułowałabym raczej na pytanie, jak sztuka działa, w jaki sposób wytwarza obszary performatywności. Pytanie, czy Pan Tadeusz to dzieło performatywne - jest źle postawione. Pana Tadeusza można zobaczyć w ramach tradycyjnej, arystotelesowskiej genologii jako epopeję narodową przynależną wielkiej tradycji epickiej, albo/i jako dzieło perfor-

${ }^{73}$ Por. artykuł E. Winieckiej, Literatura bez granic? Media digitalne $i$ ich wptyw na status sztuki słowa złożony do druku w „Przestrzeniach Teorii” - powołuję się na niego za zgodą Autorki. 
matywne - które możemy konstruować, uruchamiając świadomość naszych klisz czytania zmierzających do odgrywania różnych (sielankowych, historycznych, genologicznych) scenariuszy. Tak jak obraz Panny dworskie Diega Velázqueza można uznać albo za obrazek rodzajowy, scenę dworska, zgodnie z zasadą reprezentacji rozumianej jako odwzorowanie istniejącego świata, albo/i za - nazwijmy go umownie - „performans niezgodności”, czyli zainicjowany proces performatywny powodujący ciag kolejnych powtórzeń, iteracji, prób uzgadniania nierozstrzygalności ${ }^{74}$. Sekrety widzenia, wchodzenia w interakcję z utworami, obrazami, sztukami sprawia, że poruszając się w polu sztuki, zderzamy materie, oglądy, narracje. Erika Fischer-Lichte pisze, że „Teksty, obrazy i przedmioty same w sobie nie sa performatywne. Jednak w specyficznych [...] okolicznościach mogą przejawiać i aktywizować właściwości [...] konstytywne dla performatywności”75, do których należą: „nieprzewidywalność procesu lektury, ambiwalencja i siła transformacyjna, która potrafi zmienić czytającego na czas lektury , a być może i na dłużej"76.

Czym zatem sa sztuki performatywne? Jerzy Grotowski w jednym z wykładów wygłoszonych w Collège de France ${ }^{77}$ porównuje określenie francuskie les arts spectaculaires (sztuki widowiskowe, a nawet sztuki spektaklu) do nazwy angielskiej performing arts (sztuki performatywne). Pokazuje, że nie jest to tylko kwestia nazwy, ale też diametralnie różnego sensu; termin francuski dotyczy patrzenia, oglądania, podczas gdy termin angielski odsyła do działania. W pierwszym przypadku podkreślamy widzenie (tego, który ogląda), w drugim akcent położony jest na aktywność (tego, który działa). „Kiedy mówimy o sztukach widowiskowych les arts spectaculaires, mamy na myśli coś, co istnieje, ponieważ jest oglądane. [...] Sztuki widowiskowe to [...] coś, co staje się sztuką [...] w oczach tego, kto ogląda. [...] Natomiast gdy mówimy performing arts, znaczenie tego pojęcia zostaje przesunięte na tego, który działa, na działanie, na osobę ludzka, która sama jest działaniem"78. Wydaje mi się jednak, że rozbieżność w interpretacji terminów wcale nie jest taka wielka, jak sugeruje Grotowski, który proponuje też własny termin w języku francuskim arts performatifs. Oglądanie, patrzenie (odróżniane od widzenia) jest także działaniem. Powiedziałabym chętnie, że w sztukach performatywnych aktualizuje się wizualność jako doświadczenie performatywne. To raczej sama istota performatywności ujawnia się w polu, które

\footnotetext{
${ }^{74}$ Por. Tajemnica „Las Meninas”, antologia tekstów, wybór i red. A. Witko, Kraków 2006.

${ }^{75}$ E. Fischer-Lichte, Performatywność..., s. 44.

${ }^{76}$ Tamże, s. 193.

${ }^{77}$ J. Grotowski, Pierwszy wykład w Collège de France. Cytuję za: D. Kosiński, Performatyka. W(y)prowadzenia, Kraków 2016, s. 206 (dokładne dane o tekście wykładu w przypisie 4 cytowanej książki).

${ }^{7}$ Tamże, s. 206.
} 
umożliwia dokonania „pracy sztuki”. W ujęciach performatywnych to właśnie wizerunki, obrazy też „patrzą na nas”, a my oddajemy im spojrzenia. Oznacza to aranżowanie dramaturgii aktu patrzenia jako doświadczenia performatywnego. To „patrzenie na nas” nie musi pochodzić bezpośrednio z zewnętrznego wobec nas, ustanowionego jako podmiot dialogu, dzieła sztuki, ale może stanowić nasze wyobrażenie sugerowane/wmawiane obrazom (na przykład lęk przed nimi pochodzi od nas samych, ukształtowanych przez na przykład reguły kulturowe, scenariusze dramaturgiczne, którym nieświadomie podlegamy lub które świadomie wykorzystujemy, dokonując własnych kreacji. Na chwilę zatem nasze spojrzenie splątuje się z obrazem, który pokazuje się nam takim, jakim go sami stworzyliśmy. Więc może, oglądając, działamy, używając obrazu do jego kreacji.

Literatura i teatr, widzenie i działanie spotykają się ze sobą na gruncie sztuki rozumianej i ujmowanej z perspektywy performatywnej (która, dodajmy, też ma już sporą liczbę odsłon...).

\section{Performatywność - działanie w przestrzeni kwantowej}

Niezależnie jednak od tego, czy spektakl będą budować dramaty, metadramaty czy „teksty dla teatru” (najczęściej prowadzące w stronę publicystyki, polityki, historii, spychające ze sceny uznany za „literacki” dramat, czyli w założeniu mający kanoniczna postać i mogący być oceniany w kategoriach poetyki i konwencji literackich bądź teatralnych), mamy dziś do czynienia przede wszystkim z przebudową naszego (jako widza i badacza) myślenia teoretycznego (nie bałabym się powiedzieć: wręcz przestrajania światopoglądu z binarnego na antybinarny). Istnieje zatem, moim zdaniem, pewna sprzeczność i niezborność między tym, co widzimy na scenie, między przekształceniami instytucji teatru, zmianami pracy w teatrze, choćby poprzez powołanie nowego zawodu dramaturga, a proponowanym dyskursem teoretyczno-krytycznym, który stara się te zjawiska ując, opisać, wyjaśnić. Zachodzi więc paradoks: $\mathrm{z}$ jednej strony jest chętnie przyjmowana teoria Lehmanna, a zwłaszcza wiara w demonizowane „teksty dla teatru”, która to niefortunna nazwa, marginalizujacca dramat, prowadzi do wzmacniania opozycyjności dramatu jako literatury wobec sztuki teatru, z drugiej strony dokonuje się wspaniała praktyka teatralna z udziałem wielkiego dramatu, pokazująca, że nie zapomniano o literaturze. Polemizując z Lehmannem, można szukać miejsca dla nowego określenia sensu i tożsamości dramatu także właśnie w performatywności.

Oto rozbrojony zostaje i uczyniony niemożliwym do utrzymania anachroniczny dyskurs teatrologiczny wierzący jeszcze do niedawna $\mathrm{w}$ istnienie 
obiektywnej historii dramatu i teatru rozumianej jako zapis rozwijających się norm, konwencji, stylów. Zmiany, które nastapiły w teatrze (analogiczne do zmian unicestwiających oczekiwania, jakie żywiono niegdyś wobec historii literatury pojmowanej jako dzieje linearnie następujących po sobie, ewentualnie co najwyżej - i to tylko do pewnego czasu - przemiennych, epok, prądów, kierunków, - izmów, a idąc jeszcze dalej, podobne także do roszczeń teorii literatury ujmowanej jako następstwo różnych metodologii, przełomów, zwrotów), doskonale można wpisać w doświadczenia innych sztuk.

Spory o dramat jako interpretację, adaptację, przekład, wydają się już dziś anachroniczne, a powrót do nich, w moim odczuciu, może już tylko mieć wymiar historyczny. Sadzę tak, ponieważ od lat pięćdziesiątych XX wieku, a już na pewno po przełomie wieków i wejściu w XXI stulecie, zmieniło się nasze spojrzenie na świat, nasz sposób ujmowania zjawisk i podejścia do siebie samych i naszych procesów poznawczych. Nie miejsce tu na szczegółowe omówienia rzeczy skądinąd znanych, powtarzanych wielokrotnie (rewolucja w fizyce i w filozofii, kres logocentryzmu, odkrycie podświadomości...).

Niemożliwy stał się już dyskurs „wyższościowy”, istniejący zarówno w wersji „meta-” (metateatralny, metadramatyczny, czyli o charakterze metajęzykowym), ale też realizowany jako - „dla” (dla teatru, przeznaczony dla sceny). Słowa (jak ujął to humorystycznie Jacek Wachowski ${ }^{79}$ ) na „p” (performans, performer, performatywność, a dodać by trzeba jeszcze przedstawienie, powtórzenie, przepisanie...) uzupełnił dyskurs używający słów zaczynających się na „re” (rekonstrukcja, reprezentacja, reprint, retusz, renowacja, remake...), a także na „nie” (nie-teatr, nie-miejsce, nie-sztuka, nie-pamięć...), a ostatnio na „u” (pamiętne u-krzesłowienie, a potem już u-książkowienie, u-filmowienie...). Przechodzimy z myślenia linearnego, hierarchicznego, rozgraniczające sztuki na polowe i czasowe, na światopogląd dramatyczny, zdarzeniowy, wielowymiarowy, umożliwiający Bachtinowski „chronotop” i Derridiańską „nierozstrzygalność”. W pierwszym podejściu dominowało wyodrębnianie, w drugim główną rolę odgrywa - jak sądzę splątywanie. Na naszych oczach - powtórzmy - „tekstowy świat” zmienia się w „świat splątany”.

\section{"Tekstowy świat" czy „splątany świat"?}

„Tekstowy świat” patronował XX wiekowi, natomiast wiek XXI powoli zmienia się w „świat splątany”. Oba terminy nie są tylko zwykłymi metaforami literackimi ani nie stanowią toposów kulturowych, ale odnoszą się

${ }^{79}$ J. Wachowski, O modnych stowach na „p” albo w obronie Barona Münchhausena, „Dialog” 2012, nr 9, s. 168-176. 
do zjawisk określających nasz stosunek do świata ujmowany w regułach humanistyki. Powiedziałabym więcej - próg XXI wieku przedefiniował dość radykalnie podstawowe kategorie ujmowania stosunku sztuki do rzeczywistości, wskazując performatywność jako możliwy sposób widzenia, doświadczania i rozumienia świata.

Oczywiście pojęcie tekstu ewoluowało, wyzwalając się już od czasu poststrukturalizmu z pęt trzech czynników: odgraniczania, wyrażania i strukturalizacji (zgodnych z definicją tekstu Jurija Łotmana). Tekst w literaturoznawstwie funkcjonuje już zupełnie inaczej. Anna Burzyńska, charakteryzując poststrukturalistyczne redefinicje tego pojęcia, podkreśla rozumienie „tekstu” jako praktyki, akcentuje jego dynamiczność, pisze, że to otwarty proces, „permanentnie wytwarzajacego znaczenia [...] i wywołujacego pozatekstowe "efekty»" ${ }^{00}$. Dodaje też, przywołując sądy niektórych performatyków o teatrologicznych rodowodach (na przykład Fischer-Lichte), że tak rozumiane ujęcie tekstu zbliżyło się do definicji performansu. „A nawet można śmiało powiedzieć, że między tak rozumianym tekstem a performansem nie ma żadnej różnicy" ${ }^{1}$. Można tak powiedzieć, ale tylko w przypadku, gdy mówimy o performansie ${ }^{82}$ i łączymy redefiniowany tekst $\mathrm{z}$ teatrologicznie rozumianym performansem, akcentując działanie, czynnościowy charakter oraz sprawczość ich obu. Jednak czy już w takim przypadku możemy mówić o performatywności? Performatywności nie da się sprowadzić, jak często twierdzą teatrolodzy, do działania i sprawczości. Performatywność to dla mnie kategoria odwołująca się do zmiany opcji w oglądaniu świata na niebinarną. Współczesny stosunek do pojęcia tekstu wymagałby osobnej rozprawy, niemieszczącej się, rzecz jasna, w ramach tego skromnego szkicu.

Powiedzmy zatem krótko: jak nie da się już dłużej utrzymać postrzegania tekstu jako stabilnego, ujętego w ramy, artefaktu, tak samo trudno operować toposami „teatru obrazu świata”, czy nawet „teatru figury świata”. Napisałam kiedyś, że może pora przewrotnie ustanowić kolejny topos „teatru bez świata”. Sądzi się nieraz także, że można traktować „świat jako performans". Sprzyja takiemu myśleniu wspomniane już tu ujęcie przejścia od „kultury jako tekstu” do „kultury jako performansu” ${ }^{83}$. Można rozumieć to jako podobieństwo kultury do przedstawienia, w sensie performansu, albo też kultury jako narzędzia wytwarzania performatywności. Kultura produkuje przestrzenie performatywne, w których „wytwarzany” jest świat.

${ }^{80}$ A. Burzyńska, Dekonstrukcja, polityka i performatyka, Kraków 2013, s. 273.

${ }^{81}$ Tamże, s. 273.

${ }^{82}$ Por. także na przykład J. Loxley, Performatywność i teoria performansu, tłum. M. Borowski, M. Sugiera, „Didaskalia” 2012, nr 101, J. Loxley, Performativity, London and New York 2006.

${ }^{83}$ Por. E. Fischer-Lichte, Estetyka performatywności... 
Granic takich działań nie da się precyzyjnie wyznaczyć ani do końca przewidzieć, budują one bowiem rodzaj nieoczekiwanych splątań łączących pojęcia, stany, działania, ludzkich i nieludzkich aktantów.

Tekst się zmienił, otworzył, przekroczył granice obrazu, wychylając się ku anamorficznym przestrzeniom, rozchwiał ramy kadru, wkraczając nie tylko na passe-partout, niekiedy stawał się rodzajem Derridiańskiego parergonu. Już nie tyle my oglądamy obrazy, ale - jakby powiedział Mitchell „obrazy patrzą na nas”, „czegoś od nas chcą”. Oddajemy więc na powrót im nasze spojrzenie - konstruujemy je od początku.

Bardzo dobrze ujmuja procesy zmiany rozumienia tekstu metafory „pojemnika” i „laboratorium”, wprowadzone przez Ryszarda Nycza. W pierwszym przypadku oznacza to odejście „od nowoczesnej ideologii tekstu jako pojemnika odizolowanego od świata autonomicznego laboratorium standardowych procedur reprezentacji, zabezpieczania, przenoszenia i odbierania znaczenia" ${ }^{84}$. W drugim, postulowanym przez Nycza rozumieniu, wiąże się on z widzeniem „(Latourowskiego z ducha) ujęcia laboratorium tekstu jako węzła otwartej sieci translacyjnych operacji między tym, co przyrodnicze, społeczne i dyskursywne, mediatyzującego i inwencyjnie przekształcającego relacje między umysłem, ciałem i środowiskiem" ${ }^{\text {85. }}$.

Myślę, że niewykluczające (a może nawet wspierające?) byłoby tu ujęcie polegające na odejściu od kategorii tekstu na rzecz aktów performatywnego splatania. W świecie, w którym zjawiska tracą swą jednoznaczność i stabilność, można próbować nazywać już nie stany, a czynności (jak w estetyce pojęcie „artefaktu” zastapiono „zdarzeniem”). Nycza „czynnościowa koncepcja tekstu”, czy „kultura jako czasownik” ida, jak sądzę, właśnie w tym kierunku. Ale też prowokuja do pójścia jeszcze dalej (choć może bardziej/ zbyt ryzykownie?) i Latourowskie „splatanie" ${ }^{86}$ przekształcić w kwantowe „splątanie”. A „tekstowy świat” zobaczyć, choć przez chwilę, jako „splątany świat". To terminologiczne przekształcenie splatanie/splatanie oznacza nie tylko grę językową (często będąca obiektem pomyłkowych poprawek korekty), ale jest związane z głębszym, wręcz światopoglądowym, przesunięciem, związanym z zakwestionowaniem widzenia świata człowieka i kultury

${ }^{84}$ R. Nycz, Kultura jako czasownik. Sondowanie nowej humanistyki, Warszawa 2017, s. 179 .

${ }^{85}$ Tamże, s. 179.

${ }^{86}$ Przyjmuję tu propozycję tłumaczy książki B. Latoura Splatajac na nowo to, co społeczne. Wrowadzenie do teorii aktora-sieci, Kraków 2010, z cała świadomością kontrowersyjności przekładu tytułowego słowa „reassembling” (tytuł oryginału: Reassembling the Social - An Introduction to Actor-Netwerk Theory), słowa, które oznacza „rekonstrukcje”, zaś angielskie „to assemble” to po polsku „składać”, „splatać” (podaję za przypisem na s. XXVI wstępu do polskiego wydania - przytaczaną uwagę Michała Pawła Markowskiego dotyczącą tłumaczenia oraz obszerny komentarz do decyzji samych tłumaczy dzieła, s. XXVI-XXVIII niniejszego wstępu). 
opartego na binarnym myśleniu Zachodu i przejścia do dekonstrukcji tego systemu. Bardzo często w dyskursach humanistycznych pojawia się natomiast pojęcie sieci (sama byłam skłonna posługiwać się wielokrotnie tym określeniem, ponieważ wyjątkowa obrazowość i przystawalność do procesów zachodzących wokół nas - do tego nieustannie prowokuja, skłaniaja). Latourowskie pojęcia: ANT, aktora-sieci, splatania, laboratorium ${ }^{87}$ - muszą się spodobać także (a może przede wszystkim?) osobom zajmującym się teatrem. Przecież pierwszym skojarzeniem dla teatrologa nie będzie wcale laboratorium Ludwika Pasteura, ale laboratorium Jerzego Grotowskiego. A zatem „Reduta” Juliusza Osterwy, „Teatr 13 rzędów” Grotowskiego, a także dla Artauda Thèâtre de l'Atelier, o którym pisał postulatywnie „Atelier nie jest przedsiębiorstwem, ale laboratorium" ${ }^{88}$ - oto prawdziwe Latourowskie sceny laboratorium! Sceny nieskrępowane pojęciami, ale motywowane życiem wyrażanym w systemie środków teatralnych. Z kolei z pojęciem aktantów, działających aktorów, można skojarzyć równie dobrze aktantów jako działających aktorów w analizach morfologii bajki Wladimira Proppa. Tyle tylko, że dla Latoura pojęcia „aktora” i „,sieci” są ze sobą ściśle związane. Kluczem do rozumienia koncepcji Latoura jest jednak pojęcie sieci. Dokładnie „aktora-sieci”, czyli słów równoważnych, złączonych ze sobą - jak komentuje polski tłumacz - na przykład uniwersytet rozumiany jako jeden działający organizm (aktor), w którym prowadzi się badania naukowe i kształci studentów, ale też równocześnie będący instytucją złożoną z budynków, ludzi, linii telefonicznych, komputerów itp., czyli odnoszącą się do struktury zwanej (siecia) ${ }^{89}$. Zapytajmy zatem $\mathrm{w}$ związku z interesującym nas tematem, czy działania performatywne sa sieciowe? Czy postępowanie badawcze (na przykład dotyczące sztuki) stosujące myślenie performatywne jest tożsame $\mathrm{z}$ myśleniem $\mathrm{w}$ kategoriach sieci?

Jeśli przyjąć, że sieć ma znaczenie strukturalne (jest strukturą pewnych powiązań, krawędzi i punktów/węzłów) - to myślenie performatywne nie będzie sieciowe. Jeśli natomiast wprowadzimy kategorię działań związanych z siecia, zastosowań, połączeń - to sieć zacznie przypominać działania performatywne, ale tylko powierzchownie przypominać. Sieć może być otwarta, ale dodajmy: oznaczać to będzie co najwyżej możliwa jej rozbudowę. Podobnie jak w sieciach neuronowych, które mają strukturę drzewiastą. Struktura sieci, nawet jak jest rozbudowywana, wyklucza nieprzewidywalność,

${ }^{87}$ B. Latour, Dajcie mi laboratorium a poruszę świat, przeł. K. Arbiszewski, „Teksty Drugie" 2009, nr 1-2.

${ }^{88}$ Cyt. za J. Błoński, wstęp do A. Artaud, Teatr i jego sobowtór, przekł. i wstęp J. Błoński, noty J. Błoński, K. Puzyna, Warszawa 1978, s. 8.

${ }^{89}$ K. Arbiszewski, Splatajac na nowo ANT. Wstep do „Splatajac na nowo to, co spoteczne”, [w:] B. Latour, Splatajac..., s. XXIX.

67 Humanistyka performatywna 
emergencję. W tym sensie działanie programisty-informatyka będzie się różnić od działań dramaturga-programującego działania teatralne. Pojęcie sieci, jako jednak ograniczonej lub co najwyżej otwartej struktury, mogłoby zatem zakładać pojęcie tekstu (w znaczeniu „pojemnika”). Działania sieciowe, rozumiane jako rozmaite wybory, mogłyby zatem zakładać mówienie o przedefiniowanym pojęciu tekstu („,czynnościowa koncepcja tekstu”), natomiast procedury performatywne wykraczałyby wtedy poza model sieciowy, kierując się ku teorii kwantowego splątania (które z kolei mogłoby wręcz eliminować - nawet przedefiniowane - pojęcie tekstu). Splątanie można obserwować, starać się symulować ten proces, ale jego zachodzenie jest nie do końca przewidywalne. Czastki splątuja się i rozplątują w aktach nie do końca sterowalnych przez podmiot, który chciałby tym procesem całkowicie zawładnąć.

Moim zdaniem niekonsekwencja w pismach Latoura polega na mówieniu z jednej strony o sieciach (aktor-sieć) a z drugiej utożsamianiu tej relacji z Deleuzjańskim kłączem. Nie bardzo daje się przecież pogodzić sieć (będąca struktura co najwyżej otwarta, która tworzą węzły i krawędzie) z kłączem (czyli plątanina, będąca zaprzeczeniem struktury, wykluczająca wszelkie uporządkowania). Albo więc koncepcja „aktora-sieci” (chyba jednak wewnętrznie sprzeczna) będzie zbliżać się do pojęcia struktury i działać na zasadach sieciowych, generujacych wszelkie działania tekstotwórcze, także i te zakładające „czynnościową koncepcję tekstu”, albo będzie zbliżać się do pojęcia kłącza, które moim zdaniem pojęcie tekstu dekonstruuje (zmienia?, przekształca?). Istnieje jednak i pokusa trzeciego odniesienia i uznania, że „aktor-sieć” to (ani struktura ani kłącze), ale... cząstki splątane, cząstki w stanie kwantowego splątania. Wtedy jasne staje się, że nie chodzi tu o aktorów działających w sieci ani o sieci wiążące jedynie ludzi, ale o efekt wpływania na siebie dwóch cząstek (aktora) i (sieci) w taki sposób, że gdy określimy parametry jednej, z całą pewnością możemy podać te same parametry drugiej, pozostającej z pierwszą w stanie splątania. Problem jednak w tym, że splątanie wyklucza sieć. Wydaje się, że literatura nie ma natury sieciowej, ale jest właśnie pewnym stanem splątania. Trochę jak pisanie, które wpływa na piszacego, nieoczekiwanie dyktując mu to, co samo chce wyrazić. Attridge w swej książce Jednostkowość literatury przytacza obszerny opis procesu pisania dokonany przez pisarza Johna M. Coetzeego ${ }^{90}$ :

[...] Naiwnościa jest sądzić, że pisanie to prosty dwustopniowy proces: najpierw decydujesz, co chcesz powiedzieć, potem to mówisz. Przeciwnie, jak wszyscy wiemy, piszesz, ponieważ nie wiesz, co chcesz powiedzieć. Pisanie odsłania przed tobą to, co chciałeś powiedzieć na początku. W rzeczywistości czasami wytwarza ono to, co

${ }^{90}$ D. Attridge, dz. cyt. s. 42. 
chcesz lub chciałeś powiedzieć. Może ono ujawnić (albo wyrazić) coś całkiem innego od tego, co myślałeś (albo przeczuwałeś), że chcesz powiedzieć na początku. W tym sensie można powiedzieć, że pisanie pisze nas. Pisanie pokazuje lub stwarza (i nie zawsze jesteśmy pewni, czy można odróżnić jedno od drugiego) nasze pragnienia sprzed chwili ${ }^{91}$.

Sam Latour wskazał też na inny przykład podobnej zależności, odwołując się do teatru lalkarzy.

Socjologowie są często oskarżani o traktowanie aktorów jak lalki zmanipulowane przez siły społeczne. Okazuje się jednak, że lalkarze [...] mają całkiem inne wyobrażenie tego, co sprawia, ze ich lalki robią różne rzeczy. Chociaż wydaje się, że marionetki sa najbardziej skrajnym przykładem przyczynowości bezpośredniej-podążaja wszak jedynie za sznurkami - lalkarze rzadko zachowują się tak, jakby mieli nad nimi pełną kontrolę. Mówią oni najdziwniejsze rzeczy w rodzaju, że „ich marionetki sugeruja, by zrobić coś, o czym sami nie pomyśleliby nigdy, że jest możliwe" ${ }^{92}$.

I znów mamy dwa przykłady podobnych procesów zachodzących zarówno w pisaniu, jak i rozgrywajaccych się w teatrze.

Zacznijmy od pisania. Piszacy nigdy nie poprzedza tekstu, ale tworzy się wraz z nim. Jeśli się przyjmie taka, odwrotna, zależność, wtedy łatwiej zrozumieć anegdotyczne słowa Puszkina o swojej literackiej postaci z Eugeniusza Oniegina, Tatianie, że nie wiedział, dokąd jeszcze go ona zaprowadzi. Pisanie miałoby więc charakter performatywny - mogłoby łączyć słowa i myśli, nie odnosić ich do jakiejśs reprezentacji, jakiegoś przedustanowienia. Uobecnianie stanów, przedmiotów, procesów powstawałoby zatem jako akt splątywania na nowo. W projekcie scenariusza pisania jest miejsce na zaskoczenie, sekret, tajemnicę. Pisanie zatem ma charakter performatywny nie tylko dlatego, że po pierwsze: oznacza działanie, po drugie: łączy się z ruchem ciała, po trzecie: jest linią nieopozycyjna wobec rysunku, po czwarte: jest sprawcze w sugerowaniu sposobu patrzenia (,czego chca od nas obrazy") i równoczesnym przyjmowaniu naszego widzenia (odbiór anamorficzny), po piąte: jest aktem działania, które zaskakuje, działania nieoczekiwanego, emergentnego, nieprzewidywalnego, nie do końca zrozumiałego, zawierającego sekret, skrywającego tajemnicę, wskazuje na zachodzenie aktu „splątania”. Czytelnik tego tekstu zapewne w tym miejscu może się uśmiechnaćc - pisanie to „splątanie umysłu”, szaleństwo ${ }^{93}$. Tak, w kategorii „splątania” mieściłoby się także i takie splątanie, medycznie rozumiane

${ }^{91}$ J.M. Coetzee, Doubling the Point: Essays and Interviews, ed. D. Attwell, Cambridge, Mass. 1992, za: D. Attridge, dz. cyt. s. 42.

${ }^{92}$ V. Nelson, The Secret Life of Puppet, 2002, za: B. Latour, Splatajac..., s. 84, przyp. 28.

${ }_{93}$ Por. M. Foucault, Powiedziane, napisane. Szaleństwo i literatura, wybór i oprac. T. Komendant, przeł. B. Banasiak, T. Komendant, M. Kwietniewska, A. Lewańska, M.P. Markowski, P. Pieniążek, posłowie M.P. Markowski, Warszawa 1999. 
jako obłęd (tworzenie jest obłędem, wytrąca bowiem z normalności, czyni nas otwartymi na inne zobaczenie świata, czyli jest czymś niezrozumiałym, prowokującym, zaskakującym). Pisanie jest obłędem w znaczeniu, jakie nadawał mu na przykład Antonin Artaud. Obłędem, który, jako działanie artystyczne, jest twórcze. Przechodząc w destrukcję, rozpad, nieobecność myśli, którą chce się przekazać, brak możliwości wyrażania - oznacza już tylko chorobę ${ }^{94}$.

Przejdźmy teraz do teatru. Przykład Latoura, dotyczący lalkarzy, mógłby zostać wzmocniony przez przywołanie tradycyjnego tajskiego teatru lalkowego lub japońskiego bunraku, mających wspólny kształt związany z posługiwaniem się lalką poprzez trzech aktorów. Człowiek i lalka sa sprzężeni ze soba. Ale czy jest to model sieciowy? Moim zdaniem nie. Aktor nie utożsamia się z siecią (aktor-sieć), ale pozostaje w trakcie spektaklu w stanie splątania z lalką. Nawiasem mówiąc - zarówno aktor w teatrze $n \bar{o}$, jak i aktor w bunraku przygotowują się przed spektaklem, by móc wejść w stan takiego splątania. W nō służy do tego specjalna sala lustrzana umożliwiająca skupienie i inicjację procesu zespalania się z maską.

Pozostając przy teatralnych przykładach, postawiłabym tezę, że sytuacja splattania jest doznanie katharsis. Jako widz i czytelnik nie jestem Edypem ani Antygona, ale na moment, podczas trwania spektaklu czy w procesie lektury, przejmuję te same cechy co bohaterowie, „wcielam się” $\mathrm{w}$ nich lub ich uobecniam. Ale równocześnie wiem i jednocześnie zapominam, że Edyp, Hamlet czy Antygona nie istnieją. Więc z „kim”, z „czym” uzyskuję splątanie? Nie z osobami, a z pojęciami, dodatkowo charakteryzowanymi jako antybinarne, z polem poza dobrem i złem, z przestrzenia, w której wina jest niewinnościa, $\mathrm{z}$ obszarem wyboru determinowanego losem itp. A może też z tragicznością rozumianą jako fakt dramatyzacji myśli o nieistnieniu, o śmierci, pojętej już tylko jako teatralizacja ${ }^{95}$. Doznanie katartyczne można by wtedy nazwać stanem splątania na przykład tragiczności i teatralizacji. Na czas trwania przedstawienia jestem aktorem/aktantem, ale nie działam w sieci (nie muszę realizować jakiś wytycznych gatunku, ulegać strukturom formuł teatralnych itp.), pozostaję w polu praw świata kwantowego - reaguję często niespodziewanie, zaskakując nieraz sama siebie. Akt splątania w teatrze, który, moim zdaniem, nie jest siecią ani w znaczeniu fizycznej struktury, ani w znaczeniu działania w niej aktantów,

${ }^{94}$ Por. cenne uwagi Jana Błońskiego dotyczące ocalającej roli literatury, która „ocaliła go [Artauda], ponieważ pozwoliła narzucić własne o sobie pojęcie czytelnikom”, wyrażone we wstępie do polskiego wydania Teatru Okrucieństwa Antonina Artauda. A. Artaud, dz. cyt., s. 10/11. Temat ten zasługuje, zwłaszcza wobec koncepcji estetyki afektywnej, na podjęcie.

${ }^{95}$ Por. Ph. Lacoue-Labarthe, Theatrum analyticum, [w:] tegoż, Typografie, przekł. J. Momro, A. Zawadzki, wybór, oprac. i wstęp J. Momro, Kraków 2014, s. 111. 
ale jest symulacją przestrzeni kwantowej, w której zachodzą różnorodne procesy splątania. W tym sensie teatr to nie tyle "tekstowy świat”, ale „świat splątany”. Podobny charakter ma literatura, która nie jest tworem będącym struktura sieciowa, ale „dziwną instytucja”" ${ }^{26}$, otwierająca możliwości różnorodnych splątań.

Podsumowując, można by powiedzieć, że wobec związków realnego świata z rzeczywistością teatru/sztuki można więc przyjać dwie postawy: próbować przedefiniowywać znaczenia będących dotąd w użyciu pojęć (jak na przykład tekst) lub próbować zastępować je albo wprowadzać obok istniejących inne (jak na przykład splątanie literackie). Zmiana terminologii unicestwiłaby, wyplątała (nomen omen!) humanistykę z myślenia opozycjami, na przykład odróżniania tekstu od nie-tekstu, sztuki od nie-sztuki, literatury od nie-literatury. Humanistyka performatywna mogłaby wtedy uaktywnić pokłady tkwiące w pojęciach: dramatu, dramaturgii, dramatyczności, dramaturgiczności.

\section{Pojęcie jako teoria}

Teoria dramatyczna czy dramaturgiczna? Dramat „odwojowany” z literatury czy z literatura ,,splątany”? A może już nie dramat, a dramaturgia? Ma rację Mieke Bal, pisząc, że jedno pojęcie ma moc, by stworzyć teorię ${ }^{97}$. Dotykając sporu o pojęcia, naprawdę podejmujemy dyskusję o kształtowanie nowego charakteru dyskursu teoretycznego. Co zatem poczać z dramatem? Pytanie to towarzyszyło mi od dawna, zwłaszcza wtedy, gdy pisząc o teatrze absurdu, miałam silne przekonanie, że (niezależnie od znaczeń i sposobów użycia słów dramat i teatr w językach obcych, zwłaszcza w angielskim) natura dramatu jest antybinarna, a w zjawisku nazwanym przez Martina Esslina teatrem absurdu, nie da się już teatru od dramatu oddzielić, a może nawet i od filmu czy innych sztuk...

Dziś coraz częściej niewygodne (bo brzmiące nieco staroświecko, zwiazane z tradycyjna genologia, budzące skojarzenia z decorum Arystotelesa) pojęcie dramatu zostaje zreinterpretowane, czy, jak kto woli, przepisane, a w końcu wypierane przez pojęcie dramaturgii. Pod wpływem, jak sądzę, koncepcji Lehmanna zaczęto powoli zastępować określenie dramat terminem dramaturgia.

Dariusz Kosiński przypomina, że nazwa zmieniła, a właściwie poszerzyła swój zakres znaczeniowy i wyróżnia trzy kierunki zastosowania pojęcia,

${ }^{96}$ Por. J. Derrida, Ta dziwna instytucja zwana literatura. Z Jacques `em Derrida rozmawia Derek Attridge, przeł. M.P. Markowski, „Literatura na Świecie” 1998, nr 11-12.

${ }^{97}$ Por. M. Bal, dz. cyt. 
zgodnie z którymi dramaturgia dotyczy: po pierwsze, grupy tekstów stworzonych przez jednego pisarza, napisanych $\mathrm{w}$ danym języku czy powstałych w określonej epoce, jak na przykład dramaturgia polska, dramaturgia renesansu itp. po drugie, dramaturgia obejmuje pewien „typ praktyki teatralnej polegający na tworzeniu całościowego (niekoniecznie tekstowego) scenariusza przedstawienia, jego kompozycji, widzianej jednak spoza sceny i traktowanej jako całość osadzona w rzeczywistości społecznej i historycznej"98; po trzecie, w propozycji autora, dramaturgia definiowana jest jako

pojęcie określające tę część złożonego i nieprzerwanego procesu ustanawiania rzeczywistości, która dotyczy kompozycji działań i wypadków, układu i przebiegu tego, co się dzieje i jak jest postrzegane, doświadczane. Dramat wywodzi się etymologicznie i historycznie od greckiego ta dromena, oznaczajacego rzeczy czynione, odróżniane od ta logomena - rzeczy mówionych. Cząstkę urgia wywodzi się z kolei od słowa ergon znaczącego pracę, zajęcie lub cel. W uproszczeniu dramaturgia to zatem działanie, praca tego, co czynione ${ }^{99}$.

Pierwsze użycie jest oczywiste, tradycyjne, weszło na stałe do języka, w podtekście zakłada istnienie zapisanych/utrwalonych tekstów, dramatów, sztuk, utworów scenicznych itp. Drugie znaczenie też jest znane i używane - dramaturgia zdarzeń, synonim układania planu sceny i zwracanie uwagi na kontekst pozateatralny i pozasceniczny. Trzecia propozycja byłaby z jednej strony, przynajmniej częściowo, tożsama z rozwojem tego, co zapoczatkowały prace Guya Deborda, Ervinga Goffmana, Victora Turnera, potem Jona McKenziego odnoszące się do pojęcia, szeroko rozumianej, teatralizacji rzeczywistości. A z drugiej strony byłaby bliska temu procesowi, który kiedyś określiłam jako poznanie dramatyczne ${ }^{100}$ i także związałam poprzez kategorię doświadczenia ${ }^{101} \mathrm{z}$ ustanawianiem procesów mentalnych, kognitywnych, emocjonalnych, czyli kształtowaniem odbioru.

Jeśli jednak przyjąć w rodowodzie dramatu proponowane tu rozróżnienie tego, „co czynione”, od tego, „,co mówione”, i uznać, że akcent pada na działanie, a nie na mówienie i widzenie, to „odwojowanie” dramaturgii oznaczałoby równocześnie w podtekście „odwojowanie” z piętna literatury (rozumianej jako sztuka słowa) i „odwojowanie” z piętna teatru (rozumianego klasycznie jako przedstawienie, ale i nowocześnie jako współpracę reżysera z dramaturgiem) oraz dodajmy „odwojowanie” z piętna widowiska (rozumianego, jako coś do oglądania).

${ }^{98}$ D. Kosiński, Performatyka. W(y)prowadzenia, Kraków 2016, s. 47.

${ }_{99}$ Tamże.

${ }^{100}$ Por. A. Krajewska, Poznanie dramatyczne, „Przestrzenie Teorii” 2004, nr 3-4.

${ }^{101}$ Por. taż, Doświadczenie dramatyczne a estetyka performatywna, „Ruch Literacki” 2006, nr 6 . 
Wróćmy jednak do dramatu. Jeśli z dwóch członów: działanie (ta dromena) i mówienie (ta logomena) wybierze się, jak sugeruje autor, działanie, „Jeśli znaczeniem dramatu i jego rezultatem jest akcja, to fundamentalna kategoria jego opisu jest właśnie dramaturgia rozumiana jako układ, kompozycja tego, co czynione" 102 . Autor zwraca uwagę na dynamiczny charakter kompozycji. A jeśli by wybrać mówienie? Akcentując drugą opcję, dokonajmy parafrazy powyższego cytatu, która mogłaby teraz brzmieć: „Jeśli znaczeniem dramatu i jego rezultatem jest mówienie, to fundamentalną kategorią jego opisu jest właśnie dramaturgia rozumiana jako układ, kompozycja tego, co mówione". Raz więc podkreślamy Arystotelesowskie pochodzenie dramatu związane $\mathrm{z}$ akcja, a w drugim znaczeniu utożsamiamy jego rodowód $\mathrm{z}$ - przywoływanymi już $\mathrm{w}$ tym tekście - retorycznymi rodzajami mowy/ form podawczych (genus dramaticum/mimeticum). Moim zdaniem, w tych dwóch opcjach nie ma sprzeczności. Działanie może przecież odnosić się do akcji, ale i do mowy (jako rozmaite działanie słowami). Ważne, by przywoływać je równocześnie i na równych zasadach wykorzystywać ich potencjalną performatywność. Dramat, moim zdaniem, ma naturę antybinarna, jest działaniem zwiąanym zarówno z akcja, jak i ze słowem, pozostając z nimi w stanie splątania. Dramaturgia dla mnie oznaczałaby zatem symulację trudno przewidywalnego procesu rozmaitych splątań, wykraczająca poza odwieczny binaryzm literatury i teatru, prowadzacy ku innym jakościom związanymi z przekształceniami dotyczacymi także charakteru samej literatury i teatru. Wszystko zależy od sposobów rozumienia literatury, mowy, teatru, performansu i... dramaturgii właśnie. Dramat może być performatywny nie tyle jako performans, ale wtedy, gdy wytwarza performatywny dyskurs. Mówienie pozostaje ważnym elementem teatru mającym podstawowe znaczenie w interakcjach wspólnych przestrzeni sceny, widowni i tego, co poza teatrem.

„Odwojowanie dramaturgii” zakłada jej uprzednie „zawojowanie” przez literaturę czy teatr, a może i widowisko. Zawojowanie ujawnia emocjonalnie negatywny potencjał - zawojować kogoś to podbić lub zniewolić, nawet swym urokiem... Dramaturgia odwojowana brzmi świetnie! Tyle że dramatu nie ma już dziś z czego odwojowywać...

Odwojowanie to właśnie proces pokazujący rodzenie się działania ze słowa! W słowie odwojowanie splątują się i słowa, i akcje: wojowanie z kimś, odbijanie kogoś z czyichś rąk, odwracanie zaistniałego stanu rzeczy, odwijanie zwoju, odbicie, uwolnienie od czegoś... Z kolei ergon to praca, czynienie, ale jednak także - dzieło. Zatem ergon to praca, która sama jako proces jest dziełem stwarzania.

${ }^{102}$ D. Kosiński, dz. cyt., s. 47.

73 Humanistyka performatywna 
I tu jesteśmy blisko (nie tylko) terminologicznego problemu sposobu używania czy wykorzystywania pojęć. Jeśli powiemy dramaturgia w innym, sugestia nowatorskim, użyciu, to musimy dokonać unicestwień pewnych niewygodnych odwołań (tradycyjnego, funkcjonującego nadal użycia, jako dramaturgia pisarza, dramaturgia narodowa, co oczywiste, ale - też równie tradycyjnie jednak rozumianego pojmowania - dramaturgii jako działania, nazwijmy tu skrótowo ustanawiającego, budujacego, wytwarzającego zdarzenie (literackie, teatralne, kulturowe, polityczne, medialne...). W przypadku, gdy chcemy słusznie podkreślić, że idzie nam też o włączenie sytuacji odbiorczej - uwikłanej niekiedy w stereotypy kulturowe, nawyki czytania, reguły oglądania itp. - to mamy do czynienia z aktami performatywnymi, a zatem tak pojęta dramaturgia oznacza właściwie proces performatywny. Bardzo to ciekawe i słuszne podejście.

Rozumiem chęć przeniesienia pojęcia dramaturgii także na inne obszary. Sama tak postępowałam, czyniąc z dramatu pojęcie określające przede wszystkim inne, nielinearne doświadczanie świata. Rolę dramatu, który z porządków opisu związanych z tradycyjna genologia przeszedł w dynamiczne, procesualne ujęcia genologii performatywnej oraz rozszerzył swe oddziaływanie na inne sfery życia i sztuki, a także dyskursy różnych dyscyplin, opisałam w Dramatycznej teorii literatury ${ }^{103}$, którą poprzedziły, powstajace od roku 2001 poczynając, różne artykuły i wypowiedzi konferencyjne. W mojej propozycji genologii performatywnej, w myśl której dramat stawał się i modyfikował coraz to inne obszary, nie zabrakło podkreślenia istoty jego działania dramaturgicznego, przejawiającego się w doświadczeniu i poznaniu dramatycznym. W moim przypadku nie oznaczało to w żadnym razie „wywikłania dramatu z literatury”, ale odwrotnie „uwikłanie literatury (i nie tylko jej!) w dramat" . W książce stawiam tezę, że to dramat właśnie zadziałał jak aktywna „matryca”, przyczyniając się do przekształceń samej literatury, a nawet - gdyby to nie zabrzmiało tautologicznie - powiedziałabym, że dramat zdramatyzował literaturę, dyskursy teoretyczne, fakty kulturotwórcze, społeczno-polityczne, pola szeroko pojętej sztuki.

Czy jest zatem sens „odwojowywać” dramaturgię z literatury? Uzasadnienie może być tylko jedno - pojmowanie literatury tradycyjnie jako sztuki słowa wyrażonej w tekście-artefakcie. Gdy zobaczymy literaturę w kontekście jej głębokich, wręcz ontologicznych przemian - taka walka staje się chyba już niepotrzebna. Nie ma przecież z czego wyzwalać dramatu. Dramat - chciałoby się powiedzieć - jest już sztuka wyzwoloną! A jeśli już bardzo chcielibyśmy obronić go przed zepchnięciem w tekst, to tylko przed tekstem rozumianym jako niezmienny, unieruchamiający obszar badań,

${ }^{103}$ A. Krajewska, Dramatyczna teoria literatury. Zarys problematyki, Poznań 2009. 
jakby powiedział Ryszard Nycz - „pojemnik”. Tekst odczytywany „na modłę literaturoznawczą" oznaczał bowiem, zwykle w domyśle, (jak już pisałam parokrotnie nie tylko w tym tekście) Łotmanowską definicję tekstu kultury definiowana poprzez takie cechy jak: odgraniczanie, wyrażanie, strukturalizacja, i tak pojęty, na długie lata nie pozwalał zobaczyć tego, co zaczęło powoli i konsekwentnie zmieniać wyobrażenia o układzie sił dramat/teatr, czyli zmian idących z dwóch, niekoniecznie rozbieżnych, kierunków: od strony praktyk samej sztuki oraz od strony zmian w myśleniu o sztuce (w tym także o literaturze), które po przełomie poststrukturalistycznym, zwłaszcza po dekonstrukcji i wobec uprawianej owocnie performatyki coraz trudniej można było rozdzielić. Przyjmując więc poststrukturalistyczne reinterpretacje, można by już z pojęcia performatywnej koncepcji tekstu ewentualnie skorzystać. W końcu w przypadku dramaturgii można też całkiem wyeliminować użycie kategorii tekstu (zastępując go na przykład proponowaną tu przestrzenią aktów splątania), ale czy rzeczywiście także trzeba zrezygnować z literatury? Jak pisał Paul Verlaine, „A wszystko inne - to literatura" 104 .

W dochodzeniu do nowego ujęcia dramaturgii Kosiński wyszedł od dramatu. Spróbujmy teraz jeszcze raz przyjrzeć się sposobowi definiowania dramaturgii, wychodząc od strony teatru, przywołując - opracowane do książki zbiorowej Performatyka. Terytoria - hasło Dramaturgia ${ }^{105}$ autorstwa Wojciecha Balucha. Poglądy autorów obu tekstów sa zbieżne. Chodzi mi jednak o pokazanie nie tyle definicji pojęć, co sposobów ich konstruowania. Baluch swoje wyprowadzenia poprzedza refleksja na temat roli dramaturga, które to pojęcie, oznaczające kiedyś dramatopisarza, zastapione zostało nowym zawodem i zaczęło oznaczać, mówiąc skrótowo, najpierw współpracującego z reżyserem uczestnika procesu działań określanych (dla mnie anachronicznym już) pojęciem adaptacji, a nieco później - człowieka, który z dystansu ocenia cały proces twórczy, nazywany jest wręcz „trzecim okiem" (por. artykuł Anety Kyzioł, Kim w teatrze jest dramaturg. Trzecie oko, „Polityka” z 3.04.2009), uwzględnia także perspektywę widzów, a wobec tekstów przyjmuje postawę (która ja z kolei nazwałabym dekonstrukcyjna) przekształcając je według swego uznania. Baluch określa takie działanie jako wprowadzanie nie tyle strukturalnego rozluźnienia, ale „budowania dzieła o różnorodnym stopniu spójności”, takim, że:

w jednym i tym samym przedstawieniu znajdują się fragmenty o całkowicie swobodnym przebiegu, które sąsiadują niejednokrotnie z klasycznymi rozwiązaniami

${ }^{104}$ Cytuję za J.H. Miller, O literaturze..., s. 7, motto.

${ }^{105}$ W. Baluch, Dramaturgia, [w:] Performatyka. Terytoria, pod red. E. Bal i D. Kosińskiego, Kraków 2017, s. 51-61. 
dramaturgicznymi. Wydaje się, że powodem takiego stanu rzeczy jest przesunięcie zainteresowań twórców z samego tekstu na obszar ludzkiego doświadczenia. Znacznie ważniejsze od sporu o autorytet tekstu (realizować go czy podważać) staje się samo doświadczenie pracy nad nim, obejmujace stosunek do tekstu, pamięć procesu jego wypracowywania, a także relacje międzyludzkie, swoista «dramaturgia doświadczenia». [...] interesujące dramaturgów relacje wykraczają znacznie poza granice świata przedstawionego, obejmując różnorodne aspekty i uporządkowania świata, w którym żyjemy na co dzień. Performatywny charakter najnowszej dramaturgii ujawnia się natomiast w tym, że uwolniona w działaniach dramaturgicznych energia ma nie tyle wykreować alternatywę dla naszej rzeczywistości (świat fikcyjny lub kontrnarrację), ile stać się zaczynem skutecznej przemiany nas samych ${ }^{106}$.

Zmianę tę wymuszaja przekształcenia w sposobie myślenia o teatrze, w którym dramaturg organizuje także pracę teatru jako instytucji, reaguje na sprawy związane z komentarzami w mediach, ewentualnymi protestami, tak że zaangażowanie artystyczne oznacza często zaangażowanie społeczne i szeroko rozumiane polityczne.

Jak odnieść się zatem do tak pojętej dramaturgii? Sądzić można, że opisane przez Balucha procesy zachodzace obecnie w teatrze wydają się tak rewolucyjne, ponieważ dotyczą... teatru repertuarowego. Natomiast są wyraźnie opóźnione wobec zjawisk, które dokonały się już dawno w innych przestrzeniach, w teatrach - nazwijmy je umownie eksperymentalnych, awangardowych, alternatywnych, osobnych etc. - a przede wszystkim w sztuce. Przypomnijmy choćby Apocalipsis cum figuris czy Księcia Niezłomnego Grotowskiego. Czy Grotowskiego nie można by było nazwać dramaturgiem? Zwracając się ku sztuce, porównajmy na przykład niektóre prace Mirosława Bałki, w których doświadczenie widza ma niekiedy wręcz charakter somatyczny. Co oznacza na przykład doświadczyć ciemności? Jak narracja wpływa na odbiór zaaranżowanego performansu? Przykłady można by mnożyć. Problem zrozumienia i współodczuwania traumatycznych doświadczeń i przeżyć innych ludzi, związanych ze zdarzeniami, których sami nie byliśmy uczestnikami ani świadkami, jest trudny i coraz częściej podejmowany w literaturoznawstwie. Dzisiejszy nowoczesny teatr repertuarowy przechodzi dopiero teraz drogę, jaką już dawno przeszła literatura (fragmentaryczność, postmedialność, wariantywność: materiały przed- i po-tekstowe, korekcja, hipertekstowość, iterowalność, cytowalność itp.), można by pomyśleć - korzysta z jej doświadczeń. Od otwierania dzieła po akty wymazywania. Destrukcja tradycyjnych norm, konwencji, tekstu, multimedialność, przesuwanie granic literatury w przestrzeń innych mediów i aplikowanie jej w przestrzenie życia codziennego - to już właściwie literacka codzienność. W sztuce - te zabiegi chyba zdążyły się nawet nieco

${ }^{106}$ W. Baluch, dz. cyt., s. 60. 
zestarzeć. I jeszcze sprawa performatywnego charakteru tak definiowanej dramaturgii, niepolegająca na kreowaniu świata fikcji, ale traktowana jako „zaczyn przekształcający nas samych”. W takim ujęciu performatywność oznacza siłę sprawczą teatru, jego wpływ na działania społeczne, na przykład niezgodę, protesty itp. Dla mnie ta sprawczość niekoniecznie jest już performatywna. Prawdziwą siłę performatywności takiej dramaturgii widzę we wprowadzaniu widza w stan dyskomfortu poznawczego, w uświadamianiu sobie mechanizmu działania teatru jako instancji produkującej prawdy fikcyjne i fikcje prawdziwe, wobec których musimy się jakoś zachować.

Wydaje się, że teatr repertuarowy przesuwa się w kierunku performansu (łączącego performans artystyczny z performansem społecznym, politycznym itp.). Ale jeszcze lepiej powiedzieć, że zmienia się także sens słowa teatr/ teatralność (kiedyś utożsamianych ze sztucznością lub sztuką wykonawcza). Obserwujemy proces, w którym współczesny, nowatorski, poszukujący teatr repertuarowy - paradoksalnie jako ostatnia ze sztuk - po prostu staje się sztuką performatywna.

Jesteśmy w punkcie, w którym zaczynamy żonglować nie tylko dyskursami, ale przede wszystkim pojęciami, stwarzać nowe, ale i zmieniać dawne zakresy znaczeniowe wyrazów. Pojęcia, stając się ruchomymi czy wędrującymi, zaczynają budować swe własne dramaturgie ${ }^{107}$ (widać wyraźnie, które pojęcia się lubia, uzupełniaja, a które wypierają i zastępują wrogów, które są czyje, kto ich najczęściej i w jakim kontekście używa itp.). Nasze sposoby „używania” teorii stają się coraz bardziej osobnicze i osobne, dlatego teorię nazwałam także budowaniem dramatografii ${ }^{108}$. Poszukujemy nowych rozwiązań w sposobach uchwycenia „działania” sztuki, ponieważ zmienił się generalnie nasz - spróbuję nazwać rzecz najogólniej - światopogląd humanistyczny. Po przewrocie poststrukturalistycznym otworzyły się drzwi do innego pojmowania roli języka, idei reprezentacji, sztuki, nauki, świata przyrody, bytów (ludzkich, non human being, zwierzęcych, roślinnych, ale też cyborgów, hybryd, chimer). Ani nauka (w znaczeniu oświeceniowej pewności i odwołań do ratio), ani (sztuka ze swoją funkcją autoteliczna), ani teatr (jako figura, a już tym bardziej jako obraz świata) nie odpowiadaja już naszym wizjom i problemom. Przedefiniowaliśmy dawno naukę, teatr, literaturę, sztukę.

Otóż, moim zdaniem, tradycyjne pojęcia nazywają często już inne zjawiska. Zmieniło się pojęcie tekstu, dramatu, literatury i dramaturgii. Można by metaforycznie, personifikująco powiedzieć, że dramaturgia opuszcza

${ }^{107}$ Por. A. Krajewska, Dramatografia...

${ }^{108}$ Taż, Teoria jako dramatografia, referat wygłoszony na konferencji „Retoryczność teorii literatury"(II) zorganizowanej przez Katedrę Poetyki i Teorii Literatury IFP Uniwersytetu Pedagogicznego w Krakowie, 7 listopada 2017 roku. 
literaturę, dramaturgia wychodzi z teatru, idzie na mecz, wychodzi na uliczny protest, ogląda serial na ekranie telewizora lub do tego celu używa smartfona. Ale też dramaturgia często powraca do literatury. Czy Wyspiański w Studium o Hamlecie odwojował teatr z literatury? Czy może pokazał literaturę zawojowaną przez teatr? Oba działania mogą zachodzić równocześnie i pozostawać w stanie splątania.

Rozmaite sa dramaturgie jako sposoby działania i widzenia tych działań, bo, po pierwsze, zmieniły się obiekty opisu, mamy więc do czynienia z sytuacja zmiany wręcz o charakterze ontologicznym, po drugie, zmieniło się podejście do procesu definiowania, zastapionego procesem tworzenia pola różnorodnych wyborów, ale też akceptowania równoczesności, współistnienia, splątywania..., po trzecie, wraz z przyjęciem znaczenia danego pojęcia tworzy się już całkiem inna teoria.

\section{Performatyka: nie-dyscyplina}

Performatyka nie jest dyscyplina, żeby przeciwstawiać jąjakiejkolwiek innej. I tu może od razu rozbrójmy krótko stereotyp performatyki traktowanej jako nowa dyscyplina badawcza. Otóż performatyka nie może być odrębną dyscyplina, choć często się tak potocznie mówi, z tej prostej przyczyny, że nią być nie chce, wręcz się od tego odżegnuje, stawiając siebie poza dyscyplinami (piszą o tym na przykład Richard Schechner ${ }^{109}$, Peggy Phelan ${ }^{110}$ czy Diana Taylor $\left.{ }^{111}\right)$. To bardzo ważne, ponieważ pozadyscyplinarnie rozumiana performatyka nie musi ani konkurować, ani ustawiać się w jednym szeregu z teatrologia, kulturoznawstwem, antropologią czy literaturoznawstwem. Poprzez to nie utrwalamy także podziałów i nie podsycamy dawnych antagonizmów (binaryzm!) pomiędzy dyscyplinami. Nie będę tu wchodzić w definicje, określenie zakresów i stref wpływów oraz prób wyodrębniania różnych performatyk. Interesuje mnie performatywność jako sposób działania przede wszystkim rozbijającego binarne, opozycyjne układy i takież sposoby myślenia. Performatyka to wolność - sparafrazowałabym chętnie określenie Derridy zastosowane w odniesieniu do dekonstrukcji, która przecież także nie jest dyscypliną. Skojarzenie nie jest przypadkowe - performatyka i dekonstrukcja są ze sobą sprzężone bardziej niż się wydaje ${ }^{112}$. Obie

${ }^{109}$ R. Schechner, Wstep , [w:] tegoż, Performatyka, Wrocław 2006, s. 16.

${ }^{110}$ P. Phelan, Introduction: The ends of performance, [w:] The Ends of Performance, eds. P. Phelan, J. Lane, London-New York 1998, s. 8.

${ }^{111}$ Por. D. Tylor, Performans, przekł. M. Borowski, M. Sugiera, Kraków 2018, s. 214 („Performatyka, jak sądzę, to zjawisko postdyscyplinarne w tym sensie, że nie chce stać się tradycyjną nauką i przestrzegać ściśle określonych granic; to \{bezustannie\} wyłaniające się pole”).

${ }^{112}$ Por. A. Burzyńska, dz. cyt. 
pragnęły zawsze być poza dyscyplinami. Może właśnie wraz z nimi weszliśmy w etap post- (czy raczej po-) dyscyplinarności? Jeśli zniszczymy te dwa stereotypy - uwikłania dramatu w literaturę rozumiana jako sztuka słowa, zamknięta w będącym artefaktem tekście, oraz podważymy mit performatyki jako osobnej, zamkniętej na inne języki, dyscypliny - otworzą się nowe perspektywy myślenia nie tylko o dramacie, ale także o całej humanistyce.

Wyostrzam problem, jednak czynię to po to, by pokazać, że, po pierwsze: performatyka sytuuje się poza (nie inter-, nie pomiędzy, ale nawet nie tyle post-, co właśnie poza dyscyplinami i prowadzi do wykształcenia języka mówienia o sztuce i świecie w kategoriach nieopozycyjnych), po drugie: dostrzegam konieczność zupełnie innego myślenia o sztuce, o teorii, o świecie, widzianych tu jako akty działania w przestrzeni performatywnej, w pewnym polu, w którym, jak w świecie kwantowym, mogą zachodzić akty splątania. Nie liczą się dziśs stany trwałe, stabilność, odgraniczanie, definiowanie, ale moc przepływów, tymczasowości, niepewności, emergencji itp. Performatyka jest moim zdaniem szansą na odnalezienie nowego języka, który zdolny byłby uchwycić procesualność i zmienność, niegotowość i chwilowość, nazwać zdarzenie, jako przechwytywanie możliwych utożsamień i przenikań.

Myślenie antybinarne pozwala kwestionować pytania o wszelkie kontradykcje. Akt rozgraniczania i definiowania proponuję zatem zastapić aktem splątywania i dramatyzacji. Działamy odtąd już w innej przestrzeni - organizując procesy, wywołujemy oczekiwane i nieoczekiwane skutki. Nasze działania w polu sztuki przekształcają obrazy świata, nasze dokonania w polu życia zmieniają sens czynności artystycznych. Doceniliśmy pustkę, szum, entropię, niepewność, wahanie, błąd. Już nawet nie tyle sieciowość, płynność, splatanie - ile splątanie, efekt „ruchu motyla”, anamorficzność, synestezyjność, hybrydowość, emergencja, synergia stają się bohaterami XXI wieku.

Z jednej strony stale szukamy nowych terminów, w których moglibyśmy mówić o „splątanym świecie”, z drugiej, jeśli taka możliwość się pojawia, staramy się (niepotrzebnie!) opisać takie pojęcia, używając kategorii binarnych. Moim zdaniem bierze się to, żeby powtórzyć raz jeszcze, z bardzo obciążającego myślenia dualnego związanego z kulturą Zachodu. Przykładem takiego postępowania jest nieradzenie sobie na przykład z określeniem istoty performatywności (dzielonej przez Fischer-Lichte na strukturalną i funkcjonalna, przeciwstawianą przez Worthena literaturoznawstwu etc.).

Podkreśla się bardzo często, że performatywnośćc ${ }^{113}$ ma dwa rodowody z jednej strony lingwistyczny (chodzi oczywiście o akty mowy Austina, ści-

${ }^{113}$ Próby definicyjnych przybliżeń pokazuje na przykład Performatyka. Terytoria, pod red. E. Bal i D. Kosińskiego, Kraków 2017. 
ślej performatywy), z drugiej - teatralny (chodzi oczywiście o performans). I znowu, już przy pierwszej próbie definicji, na przekór sensowi pojęcia performatywności, mamy do czynienia z myśleniem binarnym prowadzącym raz ku słowom i raz ku scenie.

Generalizując: teatrolodzy, nastawieni zwykle na konkret teatralnej sceny, będą skłonni do unikania pola literaturoznawczego (pojawiają się stale obawy o „utekstawianie” - czytaj: unieruchamianie - zjawisk, czyli czynienia z wszystkiego tekstu traktowanego „na modłę literaturoznawczą", dominują wręcz pragnienia - podtekstowo lub jawnie wyrażane - jako marzenia o „odwojowaniu” dramaturgii z literatury $\left.{ }^{114}\right)$. Literaturoznawcy z kolei w większości nie są zbyt chętni, by podejmować sprawy dramatu. Odnieść często można wrażenie, że oddychają z ulgą że performatyką teatralna, widowiskiem, performansem zajęli się... performatycy. Sami natomiast wolą interesować się aspektami teorii, pisać o związkach performatyki z innymi postawami wobec badań sztuki, na przykład z dekonstrukcja. Zwrot performatywny przyjmował się moim zdaniem w Polsce z trudem, burzył ład, do którego przyzwyczaił nas strukturalizm i semiotyka. Wraz z dekonstrukcją udało się jednak nie tylko zrozumieć i rozwijać performatykę, ale przewalczyć minione stereotypy uprawiania teorii, które z kolei pewnie wkrótce znów za chwilę staną się już tylko synonimem „minionych czasów”. Jednak myślę, że wraz z performatyką stało się coś więcej - zmieniło się podejście do humanistyki. Dopóki performatywność będziemy przypisywać temu, co istnieje tylko po stronie „sceny” (w rozmaitych jej wymiarach - dosłownych i metaforycznych, teatralnych i społecznych, sceno-graficznych i politycznych, kulturowych i estetycznych itp.) i nie uznamy performatywności także za istotę działania „literatury” (w rozmaitych jej wymiarach i kreacjach - literatury mówionej, wydanej drukiem, form dawniej określanych jako paraliterackie, liberatury, piśmienniczego performansu, pisma i mowy, odegranego rysunku, typografii, postaci cyfrowych i interaktywnych, itp.) nie zauważymy płaszczyzny, na której możemy uruchomić zasadę działania „splątanego świata”. Świata wciąż konstruowanego na nowo. Czy dramat, który tkwi u podstaw filozoficznie rozumianej performatywności, to (jakby się mogło, na pierwszy rzut oka, wydawać) określa „jedność przeciwieństw”, „aktor-sieć”, „amalgamaty kognitywne”115, pojęcia odwołujące się do dialektyki, struktury sieciowych, ujęć holistycznych, czy może dramaturgia pewnej wizji „,́wiata w działaniu”, „odblasków tragedii” „,anamorficzności odbioru”,

${ }^{114}$ Por. D. Kosiński, dz. cyt.

${ }^{115}$ Zob. A. Libura, Amalgamaty kognitywne w sztuce, Kraków 2007. Za zwrócenie uwagi na tę pozycję w trakcie niezapomnianej dyskusji o antybinaryzmie podczas naszego spotkania w Poznaniu - bardzo dziękuję Pani Profesor Elżbiecie Tabakowskiej. 
„dyskursów synestezyjnych” czy „doświadczeń syn(estetyczności)”116, nieustającego procesu określanego przez pojawiające się emergentnie stany splątania? Obserwacja natury tych splątań prowadzi do zmiany sposobów pisania o sztuce i daleko idących wniosków, służących za wskazówki w przekształceniach w uprawianiu humanistyki, która - moim zdaniem - staje się właśnie humanistyką performatywną.

Zwykle teatrolodzy nie zauważali performatywności literatury, (,sceny tekstu"), literaturoznawcy unikali pisania o performatywności tak zwanych sztuk wykonawczych (,sceny teatru”), historykom sztuki, na przykład spod znaku Panofsky'ego, też trudniej było kierować uwagę ku performatywności obrazu (,teatr obrazu”). Kulturoznawcom zawsze bliższe były rozpoznania prowadzące od rytuału, przez społeczeństwo spektaklu ku kulturze rozumianej jako performans. A zatem Butler czy Derrida?, Loxley czy de Man?, Culler czy McKenzie?, Iser czy Segdwik?, Carlson czy Attridge?, Phelan czy Schechner? Ma rację Jacek Wachowski, pisząc: „Podstawowy kłopot z performatywnością nie polega jednak na jej reinterpretacjach. [...] Mówiąc o performatywności, nie mamy pewności, o które jej rozumienie chodzi: o Austinowskie, Loxleyowskie, Butlerowskie, a może jakieś inne?"117. A zatem, moim zdaniem, należy przyjąć tę różnorodność i zaakceptować fakt, że mamy różne performanse, odmienne performatyki, wielość odcieni performatywności... Brak jednej, jasnej definicji nie musi zaraz oznaczać chaosu. Performatywność to wybór światopoglądu, wizji „,splatanego świata”. Widziałabym to raczej jako otwarcie możliwości wybierania własnych ścieżek, tworzenia nieoczekiwanych powiązań i dokonywania oryginalnych splątań. Lista książek, artykułów, haseł itp. poświęconych performatywności jest już bardzo długa. Znamienne jest to, że niemożność jednoznacznego zdefiniowania performatywności pokazuje zmianę podejścia do pojęć we współczesnej humanistyce. To humanistyka, jako dramatyczna wizja świata, wyznaczająca dyskurs, którego wcześniej w dziele nie było, stała się performatywna.

Na ile performatyka zmieniła dyscypliny? Wydaje się, że nie tylko dyscypliny, ale przekształciła diametralnie całą humanistykę. Nowa humanistyka, niezależnie, jak ją będziemy nazywać: czy humanistyką cyfrowa, czy posthumanistyka, czy neurohumanistyka, u podstaw zawsze, moim zdaniem, będzie już humanistyką performatywna.

Spierając się o definicje i nie mogąc nieraz ich uzgodnić do końca, nawet nie zauważyliśmy, że uprawiamy już inną teorię.

${ }^{116}$ Zob. M. Chaberski, Doświadczenie (syn)estetyczne. Performatywne aspekty przedstawień site-specific, Kraków 2015.

${ }^{117}$ J. Wachowski, Performer, performans, performatywność..., s. 60. 


\section{BIBLIOGRAFIA}

Arbiszewski K., Splatajac na nowo ANT. Wstę do „Splatajac na nowo to, co społeczne”, [w:] B. Latour, Splatajac na nowo to, co spoteczne. Wprowadzenie do teorii aktora-sieci, wstęp K. Arbiszewski, przekł. A. Derra, K. Arbiszewski, Kraków 2010.

Artaud A., Teatr i jego sobowtór, przekł. i wstęp J. Błoński, noty J. Błoński, K. Puzyna, Warszawa 1978.

Attridge D., Jednostkowość literatury, przeł. P. Mościcki, Kraków 2007.

Austin J.L., Jak działać słowami, [w:] J.L. Austin, Mówienie i poznawanie, przekł. B. Chwedeńczuk, Warszawa 1993.

Baggott J., Paradoks kota Schrödingera, [w:] J. Baggott, Teoria kwantowa, Warszawa 2013.

Bal M., Wędrujace pojęcia w naukach humanistycznych, przeł. M. Bucholc, Warszawa 2012.

Baluch W., Dramaturgia, [w:] Performatyka. Terytoria, pod red. E. Bal, D. Kosińskiego, Kraków 2017.

Błaszczak M., Ekrany i lustra w polskim dramacie współczesnym, Poznań 2009.

Błoński J., Wstepp, [w:] A. Artaud, Teatr i jego sobowtór, przekł. i wstęp J. Błoński, noty J. Błoński,. K. Puzyna, Warszawa 1978.

Burzyńska A., Dekonstrukcja, polityka i performatyka, Kraków 2013.

Butler J., Zapisy na ciele, wywrotowe odgrywanie, [w:] Teorie literatury XX wieku. Antologia, pod red. A. Burzyńskiej, M.P. Markowskiego, Kraków 2006.

Chaberski M., Doświadczenie (syn)estetyczne. Performatywne aspekty przedstawień site-specific, Kraków 2015.

Ciechowicz J., Ich troje. Telewizja jako osoba dramatu, [w:] Teatr-media-kultura, pod red. D. Fox, E. Wąchockiej, Katowice 2006.

Crary J., Zawieszenia percepcji. Uwaga, spektakl i kultura nowoczesna, przekł. Ł. Zaremba, I. Kurz, red. nauk. i posł. I. Kurz, Warszawa 2009.

Culler J., Literatura w teorii, przełożył M. Maryl, Kraków 2013.

Danto A.C., Po końcu sztuki. Sztuka wspótczesna i zatarcie się granic tradycji, przekł. M. Salwa, Kraków 2013.

Deleuze G., Różnica i powtórzenie, przekł. B. Banasiak i K. Matuszewski, Warszawa 1997.

Derrida J., Gorqczka archiwum. Impresja freudowska, przełożył J. Momro, Warszawa 2016.

Derrida J., Prawda w malarstwie, przekł. i posł. M. Kwietniewska, Gdańsk 2003.

Derrida J., Ta dziwna instytucja zwana literatura. Z Jacques'em Derrida rozmawia Derek Attridge, przeł. M.P. Markowski, „Literatura na Świecie” 1998, nr 11-12.

Dziadek A., Themerson i Schwitters, „Teksty Drugie” 2006, nr 4.

Eshelman R., Performatyzm, albo koniec postmodernizmu („American Beauty”), przeł. W. Szwebs, K. Hoffmann, „Przestrzenie Teorii” 2012, nr 17.

Faulstich W., Estetyka filmu. Badania nad filmem science fiction „Wojna światów” (1953/1954) Byrona Haskina, przekł. M. Kasprzyk, K. Kozłowski, przedm. i oprac. K. Kozłowski, Poznań 2017.

Fischer-Lichte E., Estetyka performatywności, tłum. M. Borowski, M. Sugiera, Kraków 2013.

Fischer-Lichte E., Performatywność, tłum. M. Borowski, M. Sugiera, Kraków 2018. 
Foster P., Beckett and Zen. A Study of Dilemma in the Novels of Samuel Beckett, London 1989.

Foucault M., Powiedziane, napisane. Szaleństwo i literatura, wybór i oprac. T. Komendant, przeł. B. Banasiak, T. Komendant, M. Kwietniewska, A. Lewańska, M.P. Markowski, P. Pieniążek, posł. M.P. Markowski, Warszawa 1999.

Franczak E., Okołowicz S. Przeciw nicości: fotografie Stanistawa Ignacego Witkiewicza, Kraków 1986

Głowacki A., Archetyptura czasu, Kokazone 2013. <www.kokazone.com>, książka zapisana w postaci OR-kodów.

Goffman E., Analiza ramowa. Esej z organizacji doświadczenia, przeł. S. Burdziej, Kraków 2010.

Grabowski A., Dramatu-pisanie jako performans. Zeznanie sprawcy, [w:] Performans, performatywność, performer. Próby definicji i analizy krytyczne, pod red. E. Bal, W. Światkowskiej, Kraków 2013.

Grabowski A., Prawdziwy Dramat Teatru. O metateatrze i metadramacie Bogustawa Schaeffera, Kraków 2017.

Grotowski J., Pierwszy wykład w Collège de France. Cytuję za: D. Kosiński, Performatyka. W(y)prowadzenia, Kraków 2016 (dokładne dane o tekście wykładu w przypisie 4 cytowanej książki).

Hejmej A., Estetyka intermedialności Stefana Themersona: („St.Francis The Wolf of Gubbio or Brother Francis`Lamb Chops”) „Pamiętnik Literacki” 2011, nr 102/3.

Ingold T., Rysowanie, pisanie i kaligrafia, „Teksty Drugie” 2015, nr 4.

Iser W., Apelatywna struktura tekstów. Nieokreśloność jako warunek oddziaływania prozy literackiej, przeł. M. Łukasiewicz, „Pamiętnik Literacki” 1980, z. 1.

Jauss H.R., Historia literatury jako prowokacja, przeł. M. Łukasiewicz, posł. K. Bartoszyński, Warszawa 1999.

Kosiński D., Performatyka. W(y)prowadzenia, Kraków 2016.

Kozłowski K., Przedmowa, [w:] W. Faulstich, Estetyka filmu. Badania nad filmem science fiction „Wojna światów”(1953/1954) Byrona Haskina, przekł. M. Kasprzyk, K. Kozłowski, przed. i oprac. K. Kozłowski, Poznań 2017.

Krajewska A., Dekonstrukcja jako problem estetyki (na przyktadzie dramatycznego dyskursu Jacques `a Derridy), „Przestrzenie Teorii” 2006, nr 6.

Krajewska A., Doświadczenie dramatyczne a estetyka performatywna, „Ruch Literacki” 2006, nr 6.

Krajewska A., Dramatografia, „Przestrzenie Teorii” 2017, nr 27.

Krajewska A., Dramatyczna teoria literatury. Zarys problematyki, Poznań 2009.

Krajewska A., Poznanie dramatyczne, „Przestrzenie Teorii” 2004, nr 3-4.

Krajewska A., Przestrzenie performatywne, „Przestrzenie Teorii” 2015, nr 24.

Krajewska A., Różewicza sztuki splatane. Interpretacja performatywna, „Przestrzenie Teorii” 2014, nr 21.

Krajewska A., Splatanie literackie, „Przestrzenie Teorii” 2012, nr 17.

Krajewska A., „Zwrot dramatyczny” a literaturoznawstwo performatywne, „Przestrzenie Teorii” 2012, nr 17.

Krakowska J., Przesiedleni. Wstep, [w:] Transfer! Teksty dla teatru. Antologia, red. J. Krakowska, Warszawa 2015. 
Kraskowska E., O dramatycznych i „dramatopodobnych” utworach Stefana Themersona, [w:] Teatr i dramat polskiej emigracji 1939-1989, pod red. I. Kiec, D. Ratajczakowej, J. Wachowskiego, Poznań 1994.

Kubikowski T., Semantyczna Wampuka, „Teatr”, 1991, nr 10.

Kyzioł A., Kim w teatrze jest dramaturg. Trzecie oko, „Polityka” z 3.04.2009.

Kyzioł A., Pamięć absolutna, „Polityka” 2018, nr 28.

Lacoue-Labarthe Ph., Theatrum analyticum, [w:] Ph. Lacoue-Labarthe, Typografie, przekł. J. Momro, A. Zawadzki, wybór, oprac. i wstęp J. Momro, Kraków 2014.

Latour B., Dajcie mi laboratorium, a poruszę świat, przełożył K. Arbiszewski, „Teksty Drugie" 2009, nr 1-2.

Latour B., Splatajac na nowo to, co spoteczne. Wprowadzenie do teorii aktora-sieci, wstęp K. Arbiszewski, przekł. A. Derra i K. Arbiszewski, Kraków 2010.

Lehmann H.-Th., Teatr postdramatyczny, przeł. D. Sajewska, M. Sugiera, Kraków 2004. Libura A., Amalgamaty kognitywne w sztuce, Kraków 2007.

Loxley J., Performativity, London-New York 2006.

Loxley J., Performatywność i teoria performansu, tłum. M. Borowski, M. Sugiera, „Didaskalia" 2012, nr 101.

Malabou C., Plastyczność u zmierzchu pisma. Dialektyka, destrukcja, dekonstrukcja, przekł. P. Skalski, Warszawa 2018.

McKenzie J., Performuj albo... Od dyscypliny do performansu, wstęp i przekł. T. Kubikowski, Kraków 2011.

Miller J.H., Linia, przekład K. Hoffmann, „Przestrzenie Teorii” 2006, nr 6.

Miller J.H., O literaturze, Poznań 2014.

Mitchell W.J.Th., Czego chca obrazy? Pragnienia przedstawien, życia i miłości obrazów, przeł. Ł. Zaremba, Warszawa 2015.

Nycz R., Kultura jako czasownik. Sondowanie nowej humanistyki, Warszawa 2017.

Performans, performatywność, performer. Próba definicji i analizy krytyczne, pod red. E. Bal, W. Światkowskiej, Kraków

Performatyka. Terytoria, pod red. E. Bal, D. Kosińskiego, Kraków 2017.

Phelan P., Introduction: The ends of performance, [w:] The Ends of Performance, eds. P. Phelan, J. Lane, London-New York 1998.

Schechner R., Performatyka, przekł. T. Kubikowski, Wrocław 2006.

Shusterman R., Myślenie ciała. Eseje z zakresu somaestetyki, Kraków 2016.

Skwarczyńska S., Zagadnienie dramatu, [w:] Problemy teorii dramatu i teatru, wybór i oprac. J. Degler, Wrocław 1988 [pierwodruk „Przegląd Filozoficzny” 1949, z. 1-2, s. 102-126].

Tajemnica „Las Meninas”, antologia tekstów, wybór i red. A. Witko, Kraków 2006.

Tylor D., Performans, przekł. M. Borowski, M. Sugiera, Kraków 2018.

Wachowski J., O modnych stowach na „p” albo w obronie Barona Münchhausena, „Dialog" 2012, nr 9.

Wachowski J., Performans, Gdańsk, 2011.

Wachowski J., Performer, performans, performatywność, czyli o miejscu performatyki $w$ badaniach teatrologicznych, [w:] Performans, performatywność, performer. Próba definicji i analizy krytyczne, pod red. E. Bal, W. Światkowskiej, Kraków 2013. 
Witkiewicz S.I., Gyubal Wahazar, czyli na przetęcach bezsensu. Nieeuklidesowy dramat $w$ czterech aktach/Vahazar or on the Uplands of Absurdity. Non-Euclidean Drama in Four Acts, przekł. C. Winiewska, adaptacja P. Fetherson, pod red. E. Sataleckiej we współpracy z M. Sady i M. Średniawa, projekt zespołu studentów PJATK, Warszawa 2017.

Worthen B.W, Między literatura a przedstawieniem, tłum. M. Borowski, M. Sugiera, Kraków 2013.

Ziomek J., Projekt wykonawcy $w$ dziele literackim a problemy genologiczne, [w:] Problemy odbioru i odbiorcy, pod red. T. Bujnickiego i J. Sławińskiego, Wrocław 1977. Żeromska E., Maska na japońskiej scenie. Od pradziejów do powstania teatru nō. Historia japońskiej maski i zwiazanej z niq tradycji widowiskowej, Warszawa 2003.

Życzyński H., Teoria dramatu, Cieszyn 1922. 
